\title{
KONSEP MANUSIA SEMPURNA MENURUT MULAAMMAD TAQÎ MISBÂH YAZDÎ
}

\author{
Oleh : \\ Saeful Anwar ${ }^{1}$, Yudi Daryadi ${ }^{2}$
}

Aqidah dan Filsafat Islam, Ushuluddin, UIN Sunan Gunung Djati Bandung',

STAI Muhammadiyah Bandung, Jl. Banteng Dalam Bandung².

Email: antifilsafat@gmail.com, yudidaryadi6@gmail.com

\begin{abstract}
Abstrak
Ilmu pengetahuan dengan pelbagai metodenya, telah menempatkan manusia pada jurang keterasingan yang dalam nan gelap. Tak hanya itu, ilmu pengetahuan yang mulanya dipahami sebagai ikhtiar bagi pemuliaan hakikat manusia, malah bergerak mendekati tubir-getir krisis kemanusiaaan multi dimensi. Manusia menjadi teralienasi akan dirinya. Berangkat dari kegagalan manusia kontemporer dalam memahami makna eksistensi manusia dalam proses menuju kesempurnaan diri. Faktor paling besar penyebab kesalahan perjalanan manusia saat ini dalam pandangan Misbâh Yazdî karena, ketidakjelasan dan ketiadaan perhatian terhadap hakikat manusia, manusia lupa akan kemengadaannya. Sehingga manusia alpa bahwa ia punya potensi untuk menjadi manusia sempurna.

Persoalan fundamental ini telah menyebabkan manusia meninggalkan fitrah yang benar dan terjerumus ke lembah kesesatan. visi manusia hari ini merupakan sesuatu yang tidak alamiah sekaligus menyimpang dari alur penciptaan sang Khaliq. Oleh karena itu, Misbâh Yazdî berusaha memfokuskan diri dalam merenungi secara mendalam sejumlah hasrat-hasrat fitri dan tendensi-tendensi (kecendrungan) alamiah yang berperan penting yang dalam pandangan Misbâh Yazdî bersifat mendasar dan prinsipil dan terdapat pada manusia. Pada terang ini, Misbâh Yazdî mengembangkan suatu skema konseptual yang menarik. Hal itu dapat ditahbiskan dengan usahanya menelusuri hakikat manusia melalui filsafat wûjud kemudian bergerak melalui analisis epistemology. Ziarah menyusuri apa yang direnungkan Misbâh Yazdî, penelitian kualitatif ini dilakukan dengan menggunakan pendekatan deskriptif dan heuristika, dengan penelitian 'studi kepustakaan' (library reseach), guna melingkupi persoalan: a) Bagaimanakah konsep Manusia Sempurna dalam diskursus Filsafat Islam?; b). Konsep Manusia sempurna seperti apakah yang dimaksud oleh Misbâh Yazdî?. Adapun sumber rujukan dan data yang digunakan dalam penelitian ini adalah karya Misbâh Yazdî, beserta berbagai sumber lainnya
\end{abstract}


yang dapat mendukung dalam pembahasan. Berbekal pada konsep ontology Mullâ Shadrâ tentang harakah jawhariyyah, Misbâh Yazdî, menyimpulkan kesempurnaan manusia sebagai evolusi dan gerak menyempurna (harakah istikmâliyah). Melalui prinsip hudûrî sebagai induk semua pengetahuan, namun pengetahuan burhânî yang di dasarkan pada silogisme-demonstratif dan pengetahuan hushûlli . Akhirnya, apa yang ditelusuri Misbâh Yazdî, merupakan bagian penting dari perjalanan ikhtiar manusia dalam menggapai kesempurnaannya yakni untuk memahami asal dan tujuan manusia. Melalui ilmu dan iman, dan iman mesti diikuti oleh amal perbuatan. Jika seseorang dapat menyaksikan hakikat kediriannya, maka ia akan menyadari bahwa kediriannya ditopang oleh Illah-nya.

Kata Kunci: Konsep manusia ,Muhammad taqî misbâh yazdî

\begin{abstract}
Science with its various methods has placed humans in the darkness of alienation. Not only that, science, which was originally understood as an effort to breed human nature, instead moved closer to the tics of a multi-dimensional humanitarian crisis. Humans become alienated from themselves. Departing from contemporary human failure in understanding the meaning of human existence in the process towards self-perfection. The biggest factor causing the error of man's current journey in the view of Misbaha Yazdî is because, obscurity and lack of attention to the nature of human beings, humans forget about its existence. So that humans are negligent that they have the potential to become perfect humans. This fundamental problem has caused humans to abandon right nature and fall into the valley of heresy. human vision today is something that is not natural as well as deviating from the path of creation of the Khaliq. Therefore, Misbâh Yazdî attempts to focus deeply on a number of natural desires and natural tendencies which play an important role which, in the view of Misbâh Yazdî, is fundamental and principle and found in humans. In this light, Misbah Yazdî developed an interesting conceptual scheme. It can be ordained with the effort to trace the nature of human beings through philosophical beliefs and then move through epistemology analysis. Pilgrimage goes through what is contemplated Misbâh Yazdî, this qualitative research is carried out using a descriptive and heuristic approach, with research 'library studies' (library reseach), to cover issues: a) What is the concept of Perfect Man in the discourse of Islamic Philosophy ?; b). What is the perfect concept of man what is meant by Misbâh Yazdî? The reference sources and data used in this study are the works of Misbâh Yazdî, along with various other sources that can support the discussion. Armed with the ontology concept of Mullâ Sadrâ about the harakah jawhariyyah, Misbâh Yazdî, concludes human perfection as an evolution and perfect movement (istikmâliyah harakah). Through the principle of
\end{abstract}


hudûrî as the mother of all knowledge, the knowledge of the bhaha is based on syllogism-demonstrative and hushûlli knowledge. Finally, what is traced by Misbâh Yazdî, is an important part of the journey of human endeavor to reach its perfection which is to understand the origin and purpose of man. Through knowledge and faith, and faith must be followed by deeds. If someone can witness the essence of his self, then he will realize that his self is sustained by his illah.

Keywords: The concept of man, Muhammad taqî misbâh yazdî

\section{A. Pendahuluan}

Al-Hikmah merupakan tawaran solutif dari para filsuf Muslim, dalam kegagalan filsafat Barat dalam memahami manusia. Al-Hikmah memiliki pengertian: pengetahuan atas totalitas realitas (meskipun definisi ini masih banyak diperdebatkan sampai hari ini). Di Hawazah Qum, filsafat sendiri umumnya dipahami sebagai ilmu yang membahas hukum umum atas maujud. Pengertian lainnya adalah ilmu yang membahas ada dengan hukum yang universalnya. Para filsus sendiri memiliki beragam pengertian tentang definisi filsafat pertama ini. ${ }^{1}$

Berdasarkan permasalahan di atas, kecemasan pun muncul, yakni apakah manusia dapat diformulasikan secara otentik menggunakan filsafat dan ilmu pengetahuan, atau malah melalui dua hal itu manusia malah menjadi terfragmentasi, dan karenanya terasing dari dirinya sendiri. Lalu dari kemelencengan ini, apakah masih ada harapan bagi seorang manusia untuk melampauinya?

Mungkin esensi manusia itu sendiri sebenarnya tidak ada, hal ini pernah diungkapkan oleh seorang filsuf masa lalu bernama Georgias. Georgias mendasarkan kesimpulan itu pada argumen: Tiada yang ada. Jika yang ada sendiri ada, maka ada tersebut takkan mampu diketahui; dan jika ia diketahui, tak ada bentuk komunikasi apapun yang dapat mengungkapnya. Lantas, jika ada itu sendiri tiada, apakah manusia yang otentik pun tiada? Jika manusia otentik itu ada, baagaimana kita dapat mengungkapnya atau penegtahuan apa yang bisa menjelaskannya? Martin Heidegger sendiri tak mampu untuk menguak hakikat manusia, alih-alih ia hanya sampai pada kesadaran "aku yang mendunia" dan mengabaikan realitas lain.

\footnotetext{
${ }^{1}$ Lihat, Muhsin Labib, Hawzah Ilmiah Qum; Ladang Peternakan Filosof Muslim Benua Lain, (AlHuda, Vol III, No. 9, 2003), hlm. 148.
} 
Ada problem eksistensi manusia yang dapat diidentifikasi dalam tiga jenis, yang mana hal ini diungkap oleh Imam Ali. Pertama, ilmuan atau rohaniawan; kedua, si pencari ilmu; ketiga, si busuk yang memburu penyeru dan ikut pada segenap arah angina, sebagaimana yang Imam Ali ajarkan pada Kumail²:

"Wahai Kumail, pengetahuan lebih baik daripada kekayaan. Pengetahuan menjaga anda sementara anda harus menjaga harta. Harta berkurang dengan pembelanjaan sedang pengetahuan berlipat ganda dengan pengeluarannya, dan hasil dari kekayaan mati bila kekayaan membusuk. Pengetahuan adalah iman yang diamalkan. Pengetahuan adalah penguasa sedang harta adalah yang dikuasai". ${ }^{3}$

Kejatuhan dan keterasingan manusia akan terjadi jika seseorang tidak memeriksa kediriannya sendiri. Di sini Imam Ali mengaja manusia untuk menyelami kedirian manusia melalui pengetahuan.

Islam sendiri menyuruh penganutnya untuk senantiasa melakukan pengembangan diri sendiri, untuk menemukan otentisitas. Alasannya, karena manusia sendiri telah diberkahi rasio, intuisi, ingatan dan sensasi indrawi. Dengan instrument itulah al-Qur;an mengajak tiap manusia untuk sampai pada kesempurnaan melalui pengetahuan.

"Dan Allah mengeluarkan kamu dari perut ibumu dalam keadaan tidak mengetahui sesuatu pun, dan Dia memberi kamu pendengaran, penglihatan dan hati, agar kamu bersyukur." (Q.S. an-Nahl: 78). ${ }^{4}$

\footnotetext{
${ }^{2}$ Kumail ibn Ziyâd an-Nakha'î adalah pemegang rahasia keimanan dan salah seorang sahabat utama Amirul Mukminin (Imam Ali a.s). Ia menempati kedudukan besar dalam pengetahuan dan prestasi dan mencapai tempat utama dalam kezahidan dan taqwa. Ia gubernur Amirul Mukminin di Hît selama beberapa waktu. Ia dibunuh oleh Hajjâj ibn Yûsuf Tsaqafî di tahun 83 H. dalam usia sembilan puluh tahun dan dikuburkan diluar kota Kûfah. Dikutip dari Sayid Syarif Radhi, hlm. 279.

${ }^{3}$ Sayid Syarif Radhi, Aforisme 147. hlm. 177.

${ }^{4}$ Ayat ini juga menolak teori Plato yang berkeyakinan bahwa jiwa (ruh) manusia sebelum datang kedunia ini berada dalam alam berbagai universal dan ide-ide (yang mana sebagai universal rasio (kulliyat ma'qul) itu disebut dengan mit'sal atau ide. Plato adalah orang pertama yang memasukan kata ide dalam dunia filsafat, dan dikarenakan segala yang ada di alam mini sekalipun sifatnya partikular telah ada di dalam ide, dengan demikian maka jiwa telah mengetahui berbagai ide dan berbagai universal ini, setelah itu jiwa datang di dunia ini. Tatkala datang di dunia, kedatangan (jiwa) di dunia atau penyatuan (jiwa) dengan tubuh merupakan suatu tirai yang menutupi seluruh pengetahuan yang pernah diketahui oleh jiwa (di dalam ide, mitsal). Tatkala jiwa datang kedunia, ia pernah mengetahui dan mengenal sesuatu, tetapi sekarang ini ia sudah tidak ingat lagi. Apapun yang dipelajari manusia di dunia ini, menurut Plato bukanlah mempelajari, tetapi mengingat kembali (anamnesis).
} 
Al-Ghazali pernah mengatakan bahwa kematian merupakan titik kesempurnaan dari manusia itu sendiri.

Allah telah memberikan kemuliaan pada manusia, dengan memberikan sebuah akal yang berfungsi untuk memahami segala sesuatu yang ada di dunia ini, termasuk mengenal Allah sebagai pencipta segala sesuatu, juga untuk memahami hikmah dan amanah yang diberikan Allah pada manusia. ${ }^{5}$

Ketidaktahuan bukanlah hambatan bagi manusia itu sendiri. Karena manusia sendiri memiliki posisi yang special. Kespesialan itu adalah daya yang dimiliki manusia untuk benar-benar mampu melampaui keterbatasan dan ketidaktahuannya itu sendiri. Kemudian, Tuhan sendiri menanamkan kecenderungan-kecenderungan yang bertentangan di dalam diri manusia, yang masing-masingnya saling tarik menarik. ${ }^{6}$

Kondisi manusia di era kontempoerer ini hadir sebagai mahluk yang telah gagal dalam mengidentifikasi dirinya (an sich)-sebagaimana terepresentasi dari sikap pemikir posodern misalnya. Heidegger sendiri pernah mengatakan bahwa "manusia lupa akan adanya".

Kondisi itulah yang membuat manusia terjebak pada sebuah kesesatan, dan hidup jauh dari hakikat manusia itu sendiri. Manusia pada akhirnya terjerembab dalam kelupaan. Sehingga hawa nafsu dan khayalan kosong diposisikan sebagai arah dan tujuan hidupnya.

Ketidakpedulian dan fokus pada hawa nafsu yang menjauhkannya dari ketidaksempurnaan ini lahir dari rutinitas-rutinitas banal yang sering dilakukan oleh manusia kontemporer. Banalitas itu misalnya, pemujaan tubuh atau perebutan kekuasaan. Sikap dan perbuatan ini tentu bertolak belakang dengan jalan yang sudah ditetapkan oleh sang Khaliq, sebagaimana dikatakan oleh Misbâh $\underline{\text { Yazdî. }}{ }^{7}$ Berdasarkan hal inilah penulis berusaha untuk fokus pada gambaran kealamiahan manusia atau dimensi fitriah manusia dalam pemikiran Misbâh Yazdî.

Bagi penulis Misbâh Yazdî memiliki konsepsi tentang manusia yang dilihat sebagai wujud yang memiliki potensi untuk menjadi sempurna, melalui sebuah gerakan penyempurnaan diri (Harakah Istikmâliyyah). Hal ini

Itulah yang menyebabkan ia mengatakan bahwa ilmu itu adalah "mengingat" (tadzakkur). Dikutip dari, Muthahhari, Mengenal Epistemologi (Jakarta: Lentera, 2001), hlm. 59.

${ }^{5}$ Abu Hamid Al-Ghazali, Hikmah Penciptaan Makhluk (Jakarta: Lentera, 2001. Cet. 3) hlm. 108-109.

${ }^{6}$ Muhammad Taqî Misbâh Yazdî, Meniru Tuhan, (Jakarta: Al-Huda, 2006), hlm. 148.

${ }^{7}$ Muhamamad Taqî Misbâh Yazdî, Jagad Diri, hlm. 1. 
ditempuh dengan berpijak pada argumentasi rasional yang didasarkan pada ontologi Mulla Shadra, yakni harakah jawhariyyah (gerak substansial), ditambah dengan epistemologi dalam merumuskan tujuan hidup manusia,

Misbâh Yazdî sendiri hadir sebagai sesosok pemikir ensiklopedis, dalam artian ia merupakan ahli dan pakar dalam berbagai bidang, seperti filsafat, ahlak, politik dan teologi.

\section{B. Pembahan}

\section{Gagasan Muhanammad Taqî Misbâh Yazdî tentang Manusia Sempurna}

Salah satu kritik Misbâh Yazdî terhadap Mullâ Shadrâ dan para filsuf Shadrian adalah ketidak cermatan dalam menggunakan istilah-istilah dalam pembahasan filsafat, terutama istilah dan konsep. Karena menyadari adanya kerancuan istilah dan pembahasannya dalam tema-tema filsafat, kemudian Misbâh Yazdî merasa perlu memulai membahas melalui analisis konsep dan mengklarifikasi, dengan harapan agar perbedaan-perbedaan dalam makna dan makna-makna teknis suatu kata dalam pembahasan filsafat dapat ditangkap dengan benar sehingga tidak mengalami distorsi.

In all languages (as far as it is known), words can be found each of which has a literal meaning, a commonly accepted meaning and a technical meaning. This is called homonymity, ishtirāk allafzī. For example, in Farsi, the term düsh has the meaning of 'last night', 'shoulder' and 'shower', and the term shìr is used for 'lion', 'milk' and 'faucet'. The existence of homonymity plays an important role in literature and poetry, but in science, and particularly in philosophy, it brings about many difficulties, especially since the different meanings for a word are often so close to each other that distinguishing them becomes difficult. Many errors are made due to this sort of homonymity, and occasionally even authorities fall into this trap.

Atas dasar itu, beberapa filsuf besar, seperti Ibnu Sina harus menjernihkan makna pelbagai istilah dan nuansa-nuansa perbedaan antara satu makna teknis dengan makna teknis lainnya sebelum memulai perbincangan filsafat yang tepat, supaya kebingungan dan kegalatan dapat terelakkan.

Munculnya homonomitas, khususnya bilamana makna-makna saling berdekatan atau bermiripan, telah membawa pelbagai masalah dalam pembahasan-pembahasan filsafat. Kesulitan-kesulitan ini berlipat ganda manakala dalam satu ilmu terdapat satu istilah yang mempunyai banyak makna teknis, seperti istilah intelek ('aql) dalam filsafat dan istilah esensial 
dan aksidental dalam logika. Di dalam filsafat sendiri terdapat istilah yang sama namun berbeda seperti term logos (bisa berarti pengetahuan, akal, atau tatanan semesta). Oleh sebab itu, kita mesti menjabarkan aneka rupa makna dan menentukan makna yang dituju dalam masing-masing pembahasan.

Setelah kita menjernihkan makna term, barulah kita akan masuk pada tema pembahasan. Yakni, apa itu kesempurnaan (al-kamâl) secara definitif? Mengapa kesempurnaan dijadikan sebagai puncak dari perwujudan eksistensi ? Makna sempurna itu sendiri bagi Murtadha Muthohari, tidak sama dengan tamâm atau lengkap. Makna lengkap berkaitan dengan suatu hal yang dipersiapkan menurut rencana tersendiri. Misalnya, bangunan rumah jika terdapat bagiannya yang kurang akan disebut tidak lengkap. Namun, di sisi lain ada suatu nilai lain yang lebih tinggi beberapa tingkat, yakni kâmil (sempurna). ${ }^{8}$ Sedangkan makna teknis kesempurnaan menurut Misbâh Yazdî, yakni:

Kesempurnaan ialah sebuah karakter hadir dalam suatu eksistensi. Akan tetapi bila dikomparasikan antara entitas yang bereksistensi dengan objek lainnya, akan didapati keberadaannya itu sebagai suatu kesempurnaan, ketika dibandingkan dengan sebagian objek lainnya. Tapi ia bisa dianggap sebagai suatu hal yang tak sempurna, ketika diperbandingkan dengan objekobjek tertentu yang selainnya [dalam kategori kelompok kedua]. Bahkan ia bisa dianggap sebagai "kekurangan" atau entitas yang mengurangi kadar nilai maujudnya (wujûdiyah) yang dilekatkan padanya. ${ }^{\text {" }}$

Kesempurnaan merupakan ketidaktuntasan dalam mewujudkan aktualitas akhir dari suatu eksistensi. Sebuah proses dalam kemenjadian, namun tidak semua eksistensi mampu mengaktualisasikan dirinya dalam mencapai titik akhir dari kesempurnaan. Ada sejumlah eksistensi yang sama sekali tidak memiliki kesiapan atau potensialitas atas kesempurnaan tertentu. Seperti semangka atau anggur yang mengandung rasa manis merupakan ciri kesempurnaan. Dalam kondisi yang sama pula kesempurnaan bagi beberapa buat justru ada apa rasa asamnya. Kenapa? Karena tiap wujud memiliki batasan esensial (al-hadd al-mâhawî) yang dimiliki secara khas oleh dirinya sendiri, dan ia bisa berubah jika batasannya sendiri dilampaui. ${ }^{10}$

\footnotetext{
${ }^{8}$ Lihat, Murtadha Mutahhari, Manusia Seutuhnya; Studi Kritis Berbagai Pandangan Filosofis, hlm 2-3

${ }^{9}$ Misbâh Yazdî, Jagad Diri, hlm. 9.

${ }^{10}$ Misbâh Yazdî, Jagad Diri, hlm, 10.
} 
Menurut Toshihiko Izutsu, ada sifat lain yang lebih penting dalam medan semantik eksistensi. Semua konsep lain, ketika menjadi predikat subjek, memberikan informasi tentangnya. Eksistensi, sebaliknya, ketika dinisbatkan kepada subjek yang nyata, tidak membawa sesuatu yang baru dan tambahan tentangnya. Dalam Islam tesis ini berasal dari al-Farabi yang merumuskan masalah tersebut secara sangat jelas inti argumen al-Farabi seperti berikut ini:

"Eksistensi" dalam proposisi "manusia ada" adalah predikat dari sudut pandang gramatika dan logika. Namun, bagi mereka yang berurusan dengan benda-benda nyata dan aktual, eksistensi bukanlah predikat menurut pengertian kata itu, karena ia tidak menceritakan apa-apa tentang sesuatu yang nyata dan aktual kecuali jika mereka diaktualisasikan, sedang predikat sejati diharuskan, satu, menunjukan sifat positif, dua, menegaskan atau menegasikan dari sesuatu fungsi yang disifati. Fungsi semacam itu tidak dimiliki oleh eksistensi ketika ia digunakan sebagai predikat dalam gramatika atau logika. Ia tidak mempunyai sesuatu yang baru untuk ditambahkan kepada isi subjek. ${ }^{11}$

Polemik di kalangan filsuf Islam masih berkisar pada masalah ashalat (kemendasaran) wujûd dan mâhiyyah; mengenai keprinsipilan dan mana yang paling awal, dan berperan sebagaai prinsip objektivasi atau individuasi maujud-maujud. Dalam tradisi metafisika Islam terdapat tiga aliran besar; pertama, Esensialisme, aliran ontologi ini meyakini bahwa eksistensi didahului oleh esensi, dan esensi atau hakikat ini dimiliki oleh entitas riil. Argumentasinya adalah, apabila wujud yang bersifat mendasar, niscaya ia (wujud) eksis pada realitas objektif, dan pasti tiap yang memiliki wujud harus memiliki wujud, dan wujud yang memiliki wujud harus memiliki wujud, begitu seterusnya. Aliran ini di wakili oleh Suhrawardi. Kedua, aliran eksistensialisme, Ibn Sina dan Mullâ Shadrâ menegaskan prinsip ashalat alwujûd dan ketidak mendasaran esensi (mâhiyyah). Salah satu argumentasi; bila yang mendasar bukanlah wujud, lalu apakah ada yang melahirkan esensi dari kenetralannya yang lain daripada wujud. Dengan demikian, aliran ini menegaskan bahwa yang punya realitas objektif ialah eksistensi, sedangkan yang subjektif, artifisial dan konstruktif dimiliki oleh esensi. ${ }^{12}$

Misbâh Yazdî berkeyakinan pada prinsip kesejatian wujud (ashalat alwujûd) sebagai masalah badîĥे (apriori) sehingga tidak perlu pembuktian, karena wujud identik belaka dengan realitas dan hakikat; sedangkan esensi

\footnotetext{
${ }^{11}$ Toshihiko Izutsu, Struktur Metafisika Sabzawari, hlm. 30.

${ }^{12}$ Muhsin Labib, Pemikiran Filsafat..., hlm. 193-194.
} 
(mâhiyyah) berbeda dengan realitas, bahkan mâhiyyah hanya eksis bila bila bersanding dengan wujud. Tanpa wujud, apapun termasuk esensi (mâhiyyah) tidak nyata. Maka bisa dikatakan Misbâh Yazdî adalah seorang penganut eksistensialis (ashâlat al-wujûd). Begitupun dengan filsuf-filsuf mazhab Qum dan Peripatetik, laiknya Ibnu Sina, Bahmanyar, Mullâ Shadrâ, Sabzawari, Thabathaba'i meyakini kesejatian eksistensi atau wuud. Salah satu alasannya ialah, jika eksistensi atau wujud bukan yang asali, maka netralitas esensi dikeluarkan oleh apa, selain daripada oleh wujud. Sebagaimana yang di tulis dalam bukunya yang berjudul Nihayah al-Hikmah, Thabathaba'i membahas persoalan ini.

Mula-mula manusia menemukan "secara hudhuri" wujud yang menjadi penghubung (al-wujud al-rabith) dalam semua proposisi yang sebetulnya adalah tindakan jiwa (action of the soul). Dari wujud penghubung itu benak manusia memperoleh konsep nominal (al-mafhum al-harfi) yang disebut dengan ast dalam bahasa Parsi atau is pada Inggris (atau adalah pada Indonesia). Setelah itu, benak memandang ast secara independen dan mengabstraksi konsep substantive wujud yang berbentuk posesif (possessive case). Baru kemudian, benak menghapuskan ikatan posesif itu dan memahami wujud dalam bentuk mutlaknya. Misalnya, dalam kalimat "Ali adalah bijak", pertama-tama makna "adalah" diperoleh dari keputusan jiwa untuk melekatkan sifat bijaksana kepada Ali, sehingga maksa "adalah" disini berlaku sebagai penghubung (kopulatif). Dan makna kopulatif ini tidak bisa terpahami kecuali dalam susunan kalimat. Kemudian "adalah" ini ditinjau oleh pikiran secara terpisah dan independen. Sebagaimana jika kata "dari" ditinjau secara terpisah ia berarti "asal" sehingga kata "dari" dikatakan merujuk kepada makna "asal”. Dengan cara ini, "pelekatan kebijaksanaan kepada Ali” yang merupakan konsep posesif ditangkap sebagai mengandung makna relasional. Setelah itu, baru pikiran kita menghapus segi posesif dan relasional kata itu dan memperoleh makna independen dan mutlak dari "wujud". ${ }^{13}$

Sesungguhnya Mullâ Shadrâlah yang dianggap mengakhiri dominasi mazhab ashâlat mâhiyyah (esensialis) dalam magnum opus-nya al-Asfâr alArba'ah mengetengahkan argumentasinya yakni;

Esensi adalah entitas buatan (maujud i'tibâri). Esensi (mâhiyyah, ke-apa-an, quiditas) adalah Setiap 'sesuatu yang muncul sebagai jawaban atas 'apa itu'. Ia adalah sesuatu yang dikenali dari substansinya. Esensi tidak menyandang sifat universal maupun particular, plural, atau singular. Manusia misalnya

\footnotetext{
${ }^{13}$ Misbâh Yazdî, philosophical Instructions..., hlm. 220.
} 
secara esensial tidak dapat dikaitkan dengan pluralitas karena apabila terikat dengan "kesatuan", maka semestinya ia (manusia) tidak mungkin banyak, juga tidak dapat dikaitkan dengan singularitas, karena manusia juga bisa banyak. Esensi manusia adalah manusia an sich tanpa kondisi apapun. ${ }^{14}$

Karena kebaikan dan kesempurnaan ada pada wujud, maka wujud merupakan yang riil dan asali. Entitas yang artifisial (i'tibâri) tak mungkin merupakan prinsip dan asal yang riil, kesempurnaan dan kebaikan. Bagi Mehdi Haeri Yazdi, argumen ini nampak lemah dan seolah melarikan diri dari masalah, karena pengusung kesejatian esensi (ashâlat mâhiyyah) akan mengajukan keberatan dengan menegaskan bahwa eksistensi bukan sumber yang-baik dan yang-sempurna, lebih jauh yang-sempurna atau kesempurnaan primer (kamal awali) dan sekunder (kamal tsanawi) berasal dari esensi itu sendiri. Tetapi Mehdi Haeri Yazdî mengetengahkan argumentasi seperti ini:

Apakah prinsip kebaikan dan kesempurnaan itu ada atau tiada? Tentu eksistensi prinsip tersebut tidak mungkin berada dalam dua kondisi sekaligus, dan karena ketiadaan mustahil melahirkan kesempurnaan dan kebaikan, maka wujud atau ada lah yang merupakan sumber dari dua prinsip tersebut. ${ }^{15}$

Kesempurnaan itu sendiri merupakan sifat sebuah tuntutan final dari eksistensi. Selain dari pada itu (yang diasumsikan sebagai kesempurnaan), sesuai dengan takaran atsar (pengaruh) yang dipunyainya untuk menolong pencapaian kesempurnaan, sebenarnya ialah mukaddimah (pendahuluan) bagi kesempurnaan sesungguhnya (atas eksistensi yang sesungguhnya). Kesempurnaan merupakan esensi (karakter) yang adanya bergantung pada wujud (eksistensi). ${ }^{16}$

Jika kita memperbandingkan antara sebatang pohon dengan sebongkah batu, maka akan didapati bahwa sebatang pohon mempunyai sejumlah kemampuan-kemampuan yang tidak terdapat pada batu. Meski semuanya tersusun atas materi yang sama yaitu atom-atom dan partikelpartikel yang membentuknya. Demikian pula jika diperbandingkan antara manusia dengan hewan, sekalipun susunan pembentuknya sama, yakni

\footnotetext{
${ }^{14}$ Lihat, Mullâ Shadrâ, al-Asfâr al-Arba'ah, juz 2, hlm 1. Dikutip dari, Muhsin Labib, Pemikiran Filsafat..., hlm. 194.

${ }^{15}$ Muhsin Labib, Hawzah Ilmiah Qum..., hlm 153.

${ }^{16}$ Misbâh Yazdî, Jagad Diri, hlm. 12.
} 
tersusun dari tulang dan daging namun hakikat kesempurnaannya berbeda. Mengapa demikian? Menurut Misbâh Yazdî penyebabnya adalah ${ }^{17}$ :

Pertama, Sebatang pohon mempunyai kesempurnaan riil dan aktual yang disebut sebagai "format tumbuhan" (shûrah nabâtiyyah) yang merupakan sumber bagi lahirnya rangkaian kerja dan implikasi spesifik pada tumbuhtumbuhan. Sebagaimana tetumbuhan mempunyai kesempurnaan secara potensial yang tidak dimiliki oleh benda mati (untuk dapat mencapainya). Adalah sesuatu yang bersifat aksiomatis (badîĥे) bahwa manakala tumbuhan mempunyai aktualitas (fi'liyah) dan daya-daya, maka ia bukan hanya tidak kehilangan sifat-sifat fisikal dan daya-daya alamiahnya, bahkan lebih jauh lagi dengan memanfaatkan atribut-atribut fisikal dan daya-daya alamiah tersebut ia dapat melakukan aktivitas kerja dan melakukan gerak untuk mencapai kesempurnaan.

Kedua, adalah binatang, ia mempunyai daya-daya tetumbuhan yakni potensi untuk berkembang (al-quwâa an-nabâtiyah), disamping indera dan gerak sebagai "format kehewanan" (shûrah hayawâniyah)-nya. Binatang pun menggunakan dan memanfaatkan daya-daya tetumbuhan yang ada pada diri hewan, untuk keperluan peraihan kesempurnaan hewaninya.

Ketiga adalah manusia, dalam kasus yang sama manusia memiliki daya-daya alamiah (tetumbuhan dan kehewanan) disamping daya-daya yang dihasilkan dari "format kemanusiaan" (shûrah insâniyah). Manusia menggunakan setiap daya tersebut untuk keperluan kesempurnaan insaninya dengan kadar yang dapat memberikan atsar atau pengaruh bagi terealisasikannya tujuan tersebut.

Dapat ditarik kesimpulan dari premis tersebut bahwa eksistensieksistensi materi dapat diklasifikasikan berdasarkan kesempurnaankesempurnaan eksistensinya (wujûdiyah) kepada beberapa tingkatan. Benda mati (jamâd) berada dalam tingkat terendah, kemudian tumbuhan dan binatang berada pada tingkat menengah, sedangkan manusia berada pada tingkat teratas. Artinya selain manusia mampu mengaktualisasikan diri menjadi manusia sempurna, ia juga mampu menjadi manusia yang bersifat batu, tumbuhan, atau hewan. Melalui pengkategorian ini, Muhammad Taqî Misbâh Yazdî ingin menegaskan bahwa yang diperhatikan dan di tekankan adalah jenis dan nilai kesempurnaan, bukan masa dan ukurannya.

Seperti yang dikemukakan oleh Mullâ Shadrâ dalam prinsip alHikmah al-Muta'aliyyah adalah ambiguitas wujud (tasykîk al-Wujûd) berarti

\footnotetext{
${ }^{17}$ Misbâh Yazdî, Jagad Diri, hlm. 13-14
} 
bahwa wujud mengalami gradasi yang berbeda tergantung kualitas wujud itu sendiri. Mullâ Shadrâ menggambarkan bahwa wujud tidak berbeda pada tingkat substansinya, prioritas dan posterioritas, serta ketampakan dan ketersembunyiannya. Menurutnya, disetiap level, pastilah ia memiliki atribut yang khusus yang dikalangan filsuf dikenal dengan kuiditas, sedangkan di kalangan sufi dikenal dengan istilah A'yân al-Tsâbitah (entitas-entitas tetap). ${ }^{18}$

Wujud tidak hanya musyakkik (ambigu, gradual) tetapi juga berurutan, tidak acak, tertata mulai dari yang umum, kemudian samar, lalu khusus (bercirikan), lalu individual, dan tunggal. Gerak gradual dalam wujud dimulai dari kurang sempurna kearah yang lebih sempurna, dan tidak bergerak kearah sebaliknya. Maka Misbâh Yazdî menyatakan bahwa kesempurnaan hakiki suatu eksistensi adalah sifat atau kondisi yang merupakan tuntutan akhir sebuah aktualisasi diri sebuah eksistensi. ${ }^{19}$

Artinya Setiap eksistensi (tumbuhan dan hewan) secara alamiah menuju kesempurnaannya, namun berbeda dengan manusia mesti menggunakan dayanya untuk bergerak menuju kesempurnaan hakiki, atau ia tak ubahnya seperti hewan dan tumbuhan. Manusia dikatakan sempurna apabila ia sudah mengoptimalkan seluruh potensi yang ada dalam lingkup eksistensinya. Seperti pengetahuan manusia baru bisa dikatakan suatu kesempurnaan. Namun pada saat yang sama bebatuan dan kayu tidak memiliki potensi untuk memiliki dan menerima pengetahuan tersebut.

Perubahan esensial (thagyîrât mâhawiyah) dapat terjadi antara lain, karena adanya perubahan pada pola partikel-partikelnya, bertambah dan berkurangnya jumlah atom-atomnya, dan perubahan-perubahan internal dalam struktur atomnya, atau karena perubahan materi menjadi energi atau sebaliknya. Tiap esensi mempunyai keselarasan berdasarkan karakternya atas dasar sifat tertentu. Diantara esensi-esensi tersebut ada yang hanya dapat menerima beberapa bentuk kesempurnaan dan tidak berpotensi menerima bentuk kesempurnaan lainnya. Hanya saja kemunculan suatu esensi baru pada suatu eksistensi tertentu tidak selamanya mengharuskan lenyapnya kesempurnaan yang telah ada sebelumnya (al-kamâl al-qabliyyah).

Beberapa eksistensi yang menerima dalam terminologi filsafat disebut sebagai hâlât fi'liyah (kondisi-kondisi teraktualisasinya [nilai-nilai kesempurnaan] yang beragam yang masing-masing dari kondisi tersebut merupakan perpanjangan dari eksistensi lainnya [yakni eksistensi yang ada

\footnotetext{
${ }^{18}$ Lihat, Kholid Alwalid, Perjalanan Jiwa Menuju Akhirat, hlm, 37-38.

${ }^{19}$ Misbâh Yazdî, Jagad Diri, hlm. 16.
} 
sesudahnya] dengan tetap terjaganya kesempurnaan dan aktualitas-aktualitas (fi'liyat) yang mendahuluinya. Didasarkan Pada fakta dimana bisa didapati bahwa semua tetumbuhan memuat partikel-partikel dan materi-materi mineral yang sama disamping apa yang disebut sebagai aktualitas tumbuhan (fi'liyah nabatiyyah) yang muncul sebagai bentuk perpanjangan bagi kondisi tersedianya atom-atom dan materi-materi tersebut yang mau tidak mau telah mempersiapkan kemunculannya]. Ibnu Sina memberi definisi manusia sempurna seperti ini:

"Seorang yang memiliki ilmu yang telah sampai pada tingkatan kesucian sedemikian sehingga terlepas dari segala pengaruh materi dan keterikatan raganya. Dia berjalan dengan ikhlas ke alam tertinggi malakuti dan merasakan kelezatan-kelezatan yang lebih tinggi."

"Namun, jangan menyangka bahwa kelezatan-kelezatan semacam itu tidak dirasakan di alam materi atau selama jiwa tetap berada di tubuh, ketahuilah bahwa mereka yang telah sampai pada alam suci non-materi, alam akal, alam malakuti, dan telah menyaksikan alam jabarut, sesungguhnya mereka telah menyaksikan Jamaliyah Ilahi dan mengecap tingkatan tertinggi kelezatan. Meskipun mereka masih bersama dengan badan-jasmani namun hati mereka tidak disibukkan olehnya dan tuntutan duniawi tidak mempengaruhinya, penyaksian-penyaksian mereka terhadap Jamaliyah Ilahi telah membuatnya berpaling dari segala pengaruh duniawi. ${ }^{20}$

Secara fitriah, tiap orang mempunyai kecendrungan untuk kesempurnaan dengan mengerakan pelbagai aktivitas yang diusahakan. Suatu esensi (kesempurnaan) tidak akan muncul apabila eksistensinya tidak bergerak. Menurut Misbâh Yazdî, perbuatan yang akan membawanya pada titik kesempurnaan ini hanya mungkin jika manusia mengetahui finalitas kesempurnaan, dan finalitas kesempurnaan itu hanya dapat ditemukan dalam pengenalan atas hakikat awal dan akhir kedirian dalam hidupnya. ${ }^{21}$

\section{Dari Harakah Jawhariyyah ke Harakah Istikmâliyah}

Wacana gerak sesungguhnya telah lama menjadi perhatian para filsuf. Pergumulan ini telah ada sejak zaman Yunani kuno. Sebagaimana yang diungkapkan Domocritus bahwa perubahan sesuatu adalah perubahan dari

\footnotetext{
${ }^{20}$ Khawjah Nashiruddin Thusi, Syarh al-Isyarat wa at-Tanbihat, jilid. 3, hlm. 353. Dikutip dari, Mohammad Adlany, Kesempurnaan Tertinggi Manusia.

${ }^{21}$ Misbâh Yazdî, Iman Semesta, hlm. 20.
} 
satu bentuk ke bentuk yang lain. Sedangkan ciri atau watak alamiahnya tidak mengalami perubahan. Kemudian Aristoteles mengikuti pendapat Demokritus meyakini bahwa gerak atau perubahan yang terjadi pada sesuatu adalah perubahan bagian luar.

Karena itu, gerak atau perubahan kuantitatif dan perubahan lokal (gerak aksiden). Apa yang disebut dengan gerak? Menurut Misbâh Yazdî Gerak biasanya didefinisikan sebagai pergeseran suatu objek dari satu titik ke titik yang lain. ${ }^{22}$

Namun, di dalam istilah filsafat, gerak mempunyai pengertian yang lebih luas; pada sebuah apel, perubahan warna dari hijau menjadi kuning yang berubah lagi menjadi merah juga disebut sebagai gerak yaitu "gerak kualitatif" (harakah kayfiyyah), demikian juga pertumbuhan sebuah pohon yang besar disebut "gerak kuantitatif" (harakah kamiyyah). Dengan dasar ini, gerak kemudian dapat dikatehorikan menjadi empat jenis: gerak spasial (harakah intiqaliyyah), perputaran (harakah wad'iyyah), gerak kuantitatif" (harakah kamiyyah), dan "gerak kuantitatif" (harakah kamiyyah).

Akan tetapi, harus diperhatikan bahwa di dalam istilah filsafat, tidak semua perubahan dapat disebut dengan gerak. Pergeseran atau perubahan keadaan suatu objek dapat disebut sebagai gerak jika memenuhi dua syarat gerak, yaitu; pertama, perubahan itu tidak tiba-tiba tapi harus gradual, juga bahwa perubahan itu harus mempunyai ekstensi temporal walaupun hanya sesaat saja. Kedua, perubahan itu harus mempunyai ekstensi yang dapat dibagi secara tak terbatas, bukan kumpulan atom-atom yang tidak dapat dibagi (seperti dalam paham atomisme). ${ }^{23}$

Dapat diartikan Harakah (gerakan) dari tinjauan filsafat adalah perubahan gradual atau keluarnya sesuatu secara gradual dari alam potensial kepada alam aktual; artinya gerakan adalah perkara eksistensial dimana sesuatu melalui perantaranya secara gradual keluar dari kondisi potensial menuju kondisi aktual. Gradualnya gerakan ini bermakna bahwa bagianbagian yang diasumsikan bagi wujudnya tidak dapat dikumpulkan pada suatu masa secara bersamaan, melainkan mewujud sepanjang waktu secara gradual. $^{24}$

\footnotetext{
${ }^{22}$ Misbâh Yazdî, Gerakan Substansial, Hubungannya dengan Waktu dan Prinsipalitas Eksistensi, (Jurnal Al-Huda, Vol. III, No. 10, 2004), hlm.117.

${ }^{23}$ Misbâh Yazdî, Gerakan Substansial..., hlm. 118.

${ }^{24}$ Misbâh Yazdî, Philosophical Intructions...,hlm. 285 - 293
} 
Sebelum Mullâ Shadrâ, pandangan umum para filsuf, termasuk Ibnu Sina, menyatakan bahwa gerakan hanya terjadi pada empat kategori kuiditas: kuantitas (kam), kualitas (kayf), posisi (wadh), dan tempat (ayn). Sedangkan substansi (jawhar) dalam pandangan ini bersifat tetap karena hanya terjadi pada perubahan dan gerakan pada empat kategori tersebut. Keberatan utama jika terjadi perubahan pada substansi adalah ketidak mungkinan melakukan penetapan terhadap sesuatu. Dalam pandangan mereka, sesuatu yang dahulu adalah sesuatu yang saat ini dan sesuatu yang saat ini adalah sesuatu yang akan datang. ${ }^{25}$

Mullâ Shadrâ mengkritik rumusan gerak atau perubahan yang terjadi pada empat kategori di atas dan mengajukan satu konsep gerak yang cukup fundamental, yakni harakah jawhariyyah. Menurut Mullâ Shadrâ, tidak mungkin gerakan hanya terjadi pada aksiden karena aksiden selalu bergantung pada substansi. Jika terjadi gerakan pada aksiden, hal tersebut jelas menunjukan gerakan yang terjadi pada substansi. Jika dapat terjadi (gerakan) pada kuantitas dan kualitas serta bagian-bagiannya yang tidak terbatas di antara keduannya secara potensial, maka wujud selalu membaharu dalam identitasnya, baik pada kuantitas atau kualitas. Dengan demikian, gerakan tersebut dapat juga terjadi pada substansi sehingga merupakan hal yang memungkinkan bagi substansi untuk menguat dan menjadi lebih sempurna dalam wujud dan tanpa merusak identitas dan kesatuan substantifnya. ${ }^{26}$

Adapun gerakan seluruh aksiden adalah mengikut pada gerakan substansi ${ }^{27}$ dan segala perubahan pada aksiden adalah akibat natural substansinya; artinya kita tidak memiliki keraguan pada gerakan aksidenaksiden satu substansi, akan tetapi sebab perubahan ini adalah karena adanya gerakan pada substansinya. Dengan demikian, pelaku natural perubahan ini harus seperti pelaku itu sendiri yang mengalami perubahan, karena itu subtansilah yang menjadi pelaku natural bagi gerakan-gerakan aksidental dan ia harus bergerak.

Yang dimaksud Mullâ Shadrâ dengan gerak substansial (harakah jawhariyyah), adalah perjalanan (perpindahan) dari sebuah substansi ke subatansi lainnya, sehingga substansi menjadi rute bagi diri substansi, bukan selain-nya. Contoh gerak yang dialami makanan, asumsikan bahwa substansi yang dikonsumsi manusia itu adalah substansi padat, ia bergerak

\footnotetext{
${ }^{25}$ Kholid Alwalid, Perjalanan Jiwa Menuju Akhirat, hlm, 50.

${ }^{26}$ Kholid Alwalid, Perjalanan Jiwa Menuju Akhirat, hlm. 51.

${ }^{27}$ Misbâh Yazdî, Philosophical Intructions...,hlm, 286.
} 
kesempurnaan ketika dimakan, lalu menjadi tanaman dan substansi menjadi berkembang. Ia melanjutkan prosesnya dan menanjak dalam peringkatperingkat tumbuh-tumbuhan hingga mencapai tingkat tertinggi. Tahap berikutnya adalah peringkat paling rendah kebinatangan, yang merupakan gerak dalam kategori substansi, lalu memasuki peringkat kemanusiaan dan menjadi substansi insane. Dengan kata lain, perpindahan dari makanan ke sperma, dari sperma ke binatang adalah gerak substansial. ${ }^{28}$

Setelah menerima pandangan Mullâ Shadrâ tentang harakah jawhariyyah, Misbâh Yazdî mengecualikan dua sub tema di dalamnya, yang secara tegas ditolaknya, yaitu seputar klain bahwa gerak substansi selalu mengarah pada kesempurnaan (sair takâmuli) dan klaim tentang harakah ardhiyyah (menyamping). Muhammad Taqî Misbâh Yazdî menolak rute horizontal dalan gradasi wujud dan gerak substansi ysng dikemukakan Mullâ Shadrâ. Menurutnya, gradasi (tasykîk wujûd) hanya bersifat vertikal (thûli), karena gradualitas dalam wujud hanya bisa diinterpretasi berdasarkan prinsip kausalitas, sedangkan pada gradasi horizontal (tasykîk 'ardhî) tidak terdapat relasi kausal.

Gerakan transubstansial mencakup segala sesuatu, dimulai pada level fisikal hingga non-fisikal. Bagi Mullâ Shadrâ, entitas yang mulanya berasal dari materi pertama (al-mâddah al-ûla) dan bersatu dengan bentuk (sûrah), via gerak transubstansial, semua unsur tersebut kemudian berkembang, dari yang awalnya materi belaka menjadi gumpalan darah, menjadi dewasa, sampai hancur, namun unsur bentuk nya berkembang menjadi jiwa bergerak (an-nafs al-mutaharrikah), lalu jiwa hewan (an-nafs al-hayawaniyyah), dan jiwa manusiawi (an-nafs al-insaniyyah). Gerakan transubstansial terjadi dalam dua ranah, pada ranah materi perubahan membawa entitas pada kehancuran, sedangkan pada jiwa entitas bergerak menuju kesempurnaan. ${ }^{29}$

Menurut Misbâh Yazdî yang mengkritik pandangan Mullâ Shadrâ, mungkin hanya dirinya yang berpandangan demikian, gerak substansial tidak selalu menyempurna, seperti gerak apel yang matang ke (menjadi) apel busuk. Gerak dari kondisi matang ke kondisi buruk tidak dapat dikatakan sebagai proses menyempurna buah apel. Atas dasar ini, substansi manusia tetap bergerak, yang apabila menyempurna, akan sampai ke surga, atau sebaliknya,

\footnotetext{
${ }^{28}$ Muhsin Labib, Pemikiran Filsafat..., hlm. 238.

${ }^{29}$ Lihat, Kholid Alwalid, Perjalanan Jiwa Menuju Akhirat, hlm, 51.
} 
jika merosot, akan terperosok ke neraka. Menurutnya, harakah jawhariyyah dapat bersifat shu'ûdiyyah, bisa juga nuzuliyyah. ${ }^{30}$

Evolusi dan gerak menyempurna (harakah istikmâliyah) suatu eksistensi adalah rangkaian perubahan bertahap pada eksistensi itu sehingga sampai pada suatu sifat-wujûdiyah, yaitu nilai kesempurnaan secara riil dan aktual. Perubahan-perubahan ini dihasilkan melalui perantaraan daya-daya yang memang telah terkandung dalam suatu eksistensi yang memiliki kesiapan menerima kesempurnaan yang bersangkutan (dalam penciptaannya) dengan memanfaatkan serangkaian syarat dan kapabilitas eksternal (al-imkânat al-khârijiyah). ${ }^{31}$

Untuk menyederhanakan konsep tersebut kita analogikan melalui sebutir benih padi ketika ia tertanam di dalam tanah, dan apabila secara memadai tersedia baginya air, udara, suhu, cahaya dan persyaratan lainnya, maka ia akan membelah dan diikuti dengan munculnya tangkai-tangkai kecil dan dedaunan mungil beserta mayang-mayangnya yang pada gilirannya akan menghasilkan sekitar tujuh ratus benih lainnya.

Rangkaian perubahan ini yang dimulai dari sebulir benih padi tersebut hingga mengakibatkan munculnya sekitar tujuh ratus benih lainnya secara terminologis disebut sebagai rangkaian gerak menyempurna (harakah istikmâliyah). Sedangkan daya-daya yang terpendam pada benih biji padi tersebut yang dengannya ia dapat menghisap bahan-bahan makanan yang layak baginya dan menolak materi-materi yang membahayakannya serta mengolah unsur-unsur materi yang telah dihisapnya tadi melalui kerja dan proses tertentu sampai ia menjadi sejumlah benih yang serupa dan sejenis dengannya yang disebut sebagai 'faktor-faktor penyempurnaan' (al-'awâmil attakâmul). Sedangkan air, udara, dan unsur-unsur eksternal lainnya dinamakan sebagai 'syarat-syarat kesempurnaan' (asy-syarâit at-takâmul). ${ }^{32}$

Eksistensi tidak serta merta menuju Gerak menyempurna, namun ia bisa bersifat destruktif pada dirinya sendiri ketika apa yang menjadi factor dan syaratnya tidak dipenuhi atau tidak diusahakan. Sebagaimana yang dituturkan Misbâh Yazdî bahwa gerak menyempurna dapat bibagi kedalam dua kategori, yaitu yang bersifat perseptif (idrâkiyah) dan bersifat natural atau

\footnotetext{
${ }^{30}$ Muhsin Labib, Pemikiran Filsafat..., hlm. 240.

${ }^{31}$ Misbâh Yazdî, Jagad Diri, hlm. 17

${ }^{32}$ Misbâh Yazdî, Jagad Diri, hlm. 18.
} 
alami (thabi'iyah), atau ilmiah (berdasarkan bentuk pengetahuanpengetahuan) dan non ilmiah (tanpa berdasarkan pengetahuan). ${ }^{33}$

Persepsi atau konsepsi yang merupakan syarat dalam sebuah gerak menyempurna, adakalanya bersifat alamiah, kendati wujud yang bersangkutan mungkin tidak dapat mempersepsi wujudnya sendiri secara jelas. Yang termasuk dalam kategori ini adalah persepsi-persepsi yang instingtif hewani. Namun terkadang pula sebuah gerak-menyempurna, terjadi secara bertahap melalui sebuah proses belajar hingga menjadi sadar, tentunya kategori ini mutlak ada pada manusia sebagai makhluk yang berakal.

Manusia yang memiliki akal sehat, sadar bahwa dirinya dapat mengetahui suatu hal di luar dirinya. Karena semua itu demi pemenuhan informasi yang berkaitan dengan kebutuhannya. Menurut pemikiran Misbâh Yazdî keberlangsungan aktivitas tersebut hanya mungkin pad filsafat ${ }^{34}$ dan bermacam-macam ilmu lain. Maka dari itu, manusia yang telah terkontaminasi paham skeptisisme tak mungkin menegasi atau aktualitas ilmu pengetahuan itu sendiri. Dengan begitu, wujud bersangkutan memiliki rangkaian kemungkinan melakukan 'penyingkapan' tertentu (melalui pengetahuan) atas sejumlah realitas sebagaimana pengetahuan-pengetahuan perolehan (iktisâbi) yang ada pada manusia.

Suatu gerak menyempurna terkadang terjadi secara natural tanpa suatu kehendak manakala telah terpenuhi perkara-perkara yang menjadi syarat-syarat yang diperlukan pada wujud yang mempunyai daya yang cukup untuk sebuah proses peraihan kesempurnaan. Sebagaimana yang dikemukakan Misbâh Yazdî bahwa proses peraihan kesempurnaan dapat diwujudkan melalui kehendak dan pilihan.

Dari sudut pandang Islam, manusia itu bak sebuah kendaraan yang sedang melaju atau mengarah pada kesempurnaan dan kebahagiaan. Allah sendiri memberi kehendak bebas pada manusia sebagai sebuah anugrah

\footnotetext{
${ }^{33}$ Misbâh Yazdî, Jagad Diri, hlm. 20.

${ }^{34}$ Hampir semua filsuf menyepakati, atau setidaknya acapkali mengembalikan definisi filsafat pada pengertiannya yang paling purba, yang dirumuskan pada awal kemunculannya oleh para pemikir Yunani kuno, yakni berasal dari kata philos (pecinta) dan sophia (kebijaksanaan). Namun seiring berjalannya waktu pengertiannya selalu di sesuaikan dengan orientasi, paradigm, objek/subjek, dan metode yang digunakan oleh masing-masing filsuf. Kemudian filsafat didefinisikan sebagai pengetahuan tentang realitas segala sesuatu, menurut mazhab Qum, filsafat adalah ilmu yang membahas hukum-hukum umum Setiap maujud; yang tidak terbagi; sebuah fenomena intelektual tunggal yang mengantarkan pada realitas universal yang merupakan titik temu Setiap realitas.
} 
untuk memilih jalur kehidupan menuju kesempurnaan, agar pilihannya itu sendiri didorong atas kehendaknya pribadi. ${ }^{35}$

Jika manusia hanya diam tak melakukan pilihan apa-apa apalagi hanya berlaku taqlid, maka ia tidak akan meraih kesempurnaan. Sekalipun melakukannya sekalipun ia berada dalam jalur yang benar, keterpaksaan adalah suatu hal yang keliru. Karena manusia mesti dan wajib mendasarkan arah kehidupan menuju kesempurnaannya melalui kehendak bebasnya.

Tingkat kesempurnaan dan kemajuan pada Gerak-Ikhtiyârî (harakah Ikhtiyâriyah) sangat terkait dengan kemauan dan pilihan wujud yang sedang malakukan aktivitas 'gerak' itu sendiri kearah kesempurnaan. Dengan ungkapan lain bahwa tidak sampainya suatu maujud kepada kesempurnaan yang diharapkan bukan saja merupakan akibat dari kurangnya kemampuan atau daya-manusia secara inheren, atau karena ketidakterpenuhinya syaratsyarat dan faktor-faktor eksternalnya. Akan tetapi terkait dengan kemauan dan kehendak subjek yang bersangkutan.

Pada titik ini pengetahuan (epistemologi) ${ }^{36}$ menjadi penting sebab dijadikan sebagai instrumen atau alat mengungkap kedirian. Sebagaimana diungkapkan Misbâh Yazdî:

\footnotetext{
${ }^{35}$ Misbâh Yazdî, Freedom, hlm. 27-28.

${ }^{36}$ Epistemologi (Filsafat Pengetahuan) Islam sebagai wilayah diskursus filsafat mencakup dua pendekatan genetivus subyectivus (menempatkan Islam sebagai subyek) bagi titik tolak berpikir (starting point) dan genetivus obyectivus (menempatkan filsafat pengetahuan sebagai subyek yang membicarakan Islam sebagai obyek kajian). Epistemologi Islam menelaah bagaimana pengetahuan itu menurut pandangan Islam, bagaimana metodologinya, serta bagaimana kebenaran dapat diperoleh dalam pandangan Islam atau proposisi yang telah terbukti keabsahannya. Berbeda dengan pandangan epistemologi barat yang membuat distorsi tentang pengetahuan, para ilmuan muslim berpendapat bahwa kita bisa mengetahui bukan saja objek-objek fisik, melainkan juga objek-objek non fisik. Oleh karena itu dalam kajian epistemologi Islam kita bisa mengenal entitas-entitas nonfisik seperti konsep-konsep mental dan metafisika. Distorsi ini, misalnya dapat kita liat dari penggunaan kata science yang dibedakan dengan knowledge. "Kata science sebenarnya dapat saja diterjemahkan dengan ilmu. Seperti science, kata 'ilm dalam epistemologi Islam, tidak sama dengan pengetahuan biasa, tetapi, seperti yang didefinisikan oleh Ibn Hazm (w. 1064 M), ilmu dipahami sebagai "pengetahuan tentang sesuatu sebagaimana adanya", dan seperti science dibedakan dengan knowledge, ilmu juga dibedakan oleh para ilmuwan Muslim dengan opini ( $\left.r a^{\prime} y\right)$. Akan tetapi, di Barat ilmu dalam pengertian ini telah dibatasi hanya pada bidang-bidang ilmu fisik atau empiris, sedangkan dalam epistemology Islam, ia dapat diterapkan dengan sama validnya, baik pada ilmu-ilmu yang fisik-empiris maupun nonfisik atau metafisis. Oleh karena itu, menurut hematku, kita pada dasarnya bisa menerjemahkan kata science dengan ilmu, dengan syarat bahwa ilmu dalam epistemologi Islam tidak dibatasi hanya pada bidang-bidang fisik,
} 
Mengingat suatu kerja-'memilih' dan 'mengidentifikasi' tidak mungkin dapat dilakukan tanpa pengetahuan dan kesadaran, maka pemilihan yang baik dan tepat dengan sendirinya berkaitan erat dengan adanya pengetahuan dan kemampuan mengidentifikasi secara benar. Setiap kali wawasan pengetahuan seseorang bertambah luas dan kemampuan untuk mendapatkan pengetahuan-pengetahuan yaqîniyah bertambah besar, maka tentu saja kemampuannya dalam memanfaatkan secara benar sumbersumber tersebut bagi peraihan kesempurnaan-kesempurnaan ikhtiyârî akan menjadi semakin besar dan semakin terbuka lebar. Demikian juga halnya, setiap kali wilayah gerak bertambah luas dan syarat-syarat eksternal semakin banyak ragamnya, maka aktivitas ikhtivârî seseorang akan sangat mungkin dilakukan dengan kebebasan yang lebih besar pula. ${ }^{37}$ Mengingat pengertian pengetahuan mencakup persepsi dan kesadaran, maka banyak topik epistemologi yang dapat dikemukakan, termasuk sebagian yang tidak secara formal terkait dengan ilmu ini, seperti persoalan menyangkut wahyu, ilham, dan berbagai jenis penyingkapan serta intuisi mistis. Melalui paparannya Misbâh Yazdî hendak menunjukan suatu jalan mengenai keharusan mengenali tujuan dan jalan yang benar. Yakni melalui pengetahuan dan kesadaran. Sebagaimana dalam al-Qur'an menceritakan kisah Adam:

Dan Allah telah mengajarkan nama-nama pada Adam, lalu ia mengujarkannya pada malaikat, lalu berfirman: "sebutkanlah kepada-Ku nama benda-benda itu jika kamu orang-orang yang benar." (Q.S. AlBaqarah: 31)

Sejak masuk kedalam syurga, Adam adalah sesosok manusia, yang tentu saa dibekali pengetahuan, epistemolog, memahami dan mengetahui berbagai hakikat. Meski dalam cerita selanjutnya Adam diusir dari surga tapi Adam sudah memilih jalan hidupnya melalui pengetahuan yang ia punya. Dan kesempurnaan manusia atau setidaknya sebagian dari kesempurnaan manusia bersifat ikhtiyârî yakni mesti dicari, diusahakan tidak serta merta turun dari langit.

Bagaimana cara kita mengenali kesempurnaan. Apakah berpengetahuan adalah satu-satunya jalan untuk meraihnya atau ada jalan lain selain itu? Menurut Misbâh Yazdî selain dengan penelusuran jalan ikhtiyârî ada juga mengenali kesempurnaan hakiki manusia dalam bentuk

seperti dalam epistemologi Barat." (Mulyadhi Kartanegara. Menembus Batas Waktu: Panorama Filsafat Islam. Mizan: Bandung, cet.I., 2002: 57-5

${ }^{37}$ Misbâh Yazdî, Jagad Diri, hlm. 22 
persepsi mata batin (idrâk wijdâni) dan pengetahuan dengan penyaksian (al'ilm asy-syuhûdî), namun jalan ini hanya mampu diretas oleh mereka yang memang telah sampai pada derajat penyaksian batiniah melalui ilmu hudhûrî dan syuhûdî.

Kalau seandainya jalan untuk mengenalinya terbatas hanya apabila manusia dapat sampai pada derajat penyaksian secara hudhûrî. Maka manusia tidak mungkin meraihnya. Maka dengan demikian makrifat yang diperlukan manusia pada awalnya bukan yang termasuk dalam kategori makrifat melalui penyaksian mata batin (al-ma'rifah asy-syuhûdiyah al-wijdâniyah) melainkan berupa-pengetahuan-pengetahuan rasional atau yang disebut dengan ilmu hushûlî dimana pengetahuan-pengetahuan jenis ini diperoleh melalui burhân (pembuktian akal) atau berupa kesimpulan dari serangkaian premis-premis rasional atau juga dari dalil-dalil naqlî yang diakui dan disepakati validitasnya. $^{38}$

Misbâh Yazdî melandaskan pengetahuannya di atas prinsip hudhûrî (kehadiran). Menurutnya, pengetahuan seseorag tentang dirinya bersifat swabukti. Dalam artian ia tidak membutuhkan segenap konsep atau pengindraan, untuk menjustifikasi keberadaan dirinya sendiri. Kemudian Misbâh Yazdî menjelaskan bahwa:

Pengetahuan ini merupakan sesuatu yang yang tak bisa diuraikan dalam konsep apapun sebagaimana konsep: saya ada, yang mana disusun oleh dua konsep saya dan ada. Maka dari itu pengetahuan tentang kedirian ini bersifat langsung atau bersifat intuitif. Ia adalah pengetahuan yang langsung tentang jiwa kita sendiri, dan pengetahuan ini ialah esensi dari jiwa manusia itu sendiri. ${ }^{39}$

Pada kenyataannya pembahasan tentang 'kesempurnaan manusia' sebenarnya diperlukan bagi para penelti dan pengkaji yang berusaha mengenali apa itu kesempurnaan dan mengenali jalan untuk sampai kepadanya. Sedangkan bagi orang-orang yang sudah meraih (dengan pengetahuan penyaksian dan penyingkapan) hakikat dari kesempurnaan hakiki, maka mereka tidak memerlukam kajian ilmiah.

Dengan demikian, maka diharapkan hakikat kesempurnaan manusia sebagai sesuatu, dapat dikenali sebelum meraihnya dimana pengenalan dan pengetahuan kita tentangnya adalah sebagaimana pengenalan kita atas

\footnotetext{
${ }^{38}$ Misbâh Yazdî, Jagad Diri, hlm. 23.

${ }^{39}$ Misbâh Yazdî, Philosophical Instructions..., hlm. 107.
} 
konsepsi-konsepsi batiniah merupakan harapan yang tak beralasan. Hal ini dikarenakan tidak ada jalan lain untuk sampai kepadanya kecuali melalui jalur silogisme dimana pengetahuan yang didapat melaluinya adalah pengetahuan yang bersifat aqlî dan bukan syuhûdî, dan bisa ditentukan objekobjeknya melalui rasio. ${ }^{40}$

\section{Tahapan-Tahapan Menuju Manusia Sempurna}

\section{a. Mengenali Diri (Ma'rifat Ad-Dzât)}

Kapasitas manusia demi mencapai kesempurnaan diri sendiri melalui pengenalan potensi diri, disebut dengan Ma'rifat adz-dzat (mengenali diri). Menurut Misbâh Yazdî urgensi dalam melaksanakan penjelasan mengenai soal ini ialah dalam takaran yang tiap dari diri kita 'telah' diketahui sebagai swabukti atau secara hudhûrî (hudhĥrî̀i sini tidak mengacu pada pengetahuan yang sempurna, yang ia dapat dalam perjalanan spiritualnya sehingga tak mendapati penghalang. Dan yang demikian itu ialah hasil dari usaha 'membangun-diri' dan merupakan penyingkapannya). Maka penulis membatasi pembahasan ini pada seputar pengenalan diri dalam kerangka epistemologi Misbâh Yazdî.

Menurut Thabâthabâ'î Maksud dari ma'rifatu an-nafs berarti mengenali jiwa dengan penyaksian dari hati, dan puncak dari pengenalan ini ialah mengenali Tuhan. Dalam diri manusia terdapat serangkaian naluri, perasaan, hasrat, tendensi, keinginan, respon batin serta aktivitas-aktivitas dan kualitas-kualitas kejiwaan lainnya. Penulis hendak mencoba mengurai pemikiran Muhammad Taqî Misbâh Yazdî dan menyoroti unsur-unsur fitriah dan kecenderungan alami dan mendasar yang terdapat di dalam diri.

Dalam bukunya, al-Mabda' wa al-Ma'âd, Mullâ Shadrâ berpendapat tentang masalah fitrah, yakni "....sebagaimana disebutkan sebelumnya, (memahami) Wujud Wajib merupakan sesuatu yang fitri karena ketika manusia berhadapan dengan peristiwa-peristiwa sulit dan menakutkan, mereka secara naluriah pasrah kepada Allah dan secara otomatis berpaling kaepada Wujud itu yang merupakan sumber segala sebab dan memudahkan segala kesulitan. Inilah sebabnya mengapa kita melihat bahwa kebanyakan sufi membuktikan eksistensi Allah dan pengendalian-Nya akan urusanurusan dunia ini dengan merujuk pada keadaan pikiran dan kesadaan ketika

\footnotetext{
${ }^{40}$ Misbâh Yazdî, Jagad Diri, hlm. 24.
} 
berhadapan dengan peristiwa-peristiwa mengerikan seperti tenggelam atau kebakaran." ${ }^{41}$

Allah telah menganugrahkan fitrah kepada manusia. Sedangkan mahluk lain memiliki fitrah ini namun dalam takarannya yang lebih rendah. Imam Khomeini menggambarkan kecendrungan alamiah ini dalam kitabnya, Syarh al-Arbain Haditsan

Salah satu diantara fitrah yang dimiliki manusia adalah, kecenderungannya menuju sebuah kesempurnaan. Karena ia merupakan fitrah manusia, maka tak ada siapapun yang dapat atau berhasil menghalau dan merusak kecenderungan fitri manusia ini. Karena ia fitrah maka kecenderungan ini tidak dibentuk atau diciptakan, melainkan ia merupakan bawaan sedari lahir.

Kecendrungan seperti inilah yang selalu memotivasi dan menggerakkan seluruh potensi yang ada pada diri untuk menuju kesempurnaan. Fitrah di sini berarti bawaan yang tidak dibentuk atau diperoleh melalui usaha (muktasabah). Menurut Mutahhari, fitrah itu memiliki pola yang sama dengan kesadaran, karena keduanya sama sama mengetahui yang ia ketahui. ${ }^{42}$ Secara alamiah manusia mempunyai tendensi fitri untuk mengetahui, mengenal, dan meliputi hakikat-hakikat wujud. Arah yang secara umum diacu oleh daya persepsi ini, merupakan sarana pemuasan atas tendensi fitri yakni rasa keingintahuan.

Berdasarkan atas asumsi di atas, maka epistemologi menjadi penting sebagai alat pengenalan terhadap realitas diri. Berpangkal dari rasa kagum, maka Aristoteles memulai metafisiknya dengan argumen "setiap manusia dari kodratnya ingin tahu". Ia percaya manusia dengan potensi rasio bisa menguak enigmatik semesta yang selalu nampak tersembunyi. Sedangkan Misbâh Yazdî mendefinisi-kan epistemologi sebagai:

The phrases and statements which are used in philosophical and logical books as definitions of knowledge and science are not genuine definitions. The purpose of mentioning them is to specify its instances in some specific science or field of study. For example, logicians define knowledge as "the obtaining of the form of something in the mind," and the purpose of this definition is to specify their intended instance which is "acquired knowledge". Or it refers to the view concerning certain problems of ontology of some philosophers who define knowledge as "the presence of a non-

\footnotetext{
${ }^{41}$ Muhammad Husaini Bahesti, Metafisika al-Qur'an, terj. Ilyas Hasan, (Bandung: Arasyi, 2003), hlm. 36.

${ }^{42}$ Murtadha Mutahhari, Bedah Tuntas Fitrah, terj. Afif Muhammad, (Jakarta: Citra, 2011), hlm. 19
} 
material being to another non-material being," or "the presence of a thing to a nonmaterial existent." The purpose of these definitions is to state their view about the non-material nature of knowledge and the knowing subject. ${ }^{43}$

Menurutnya pengetahuan merupakan konsep aling jelas san swabukti (self-evident). Karena ia swabukti, maka pengetahuan mustahil diberi definisi atau dilekatkan pada istilah atau kata tertentu untuk menjelaskannya. Kemudian Misbâh Yazdî melanjutkan:

"The presence of the thing itself or its particular form or its general concept in a nonmaterial existent. In addition, we should say that it is not necessary for knowledge that the knower always should be other than the object known. It is possible, as in the case of awareness of one's own self, that there be no difference between the knower and the object of knowledge. In fact in such cases unity is the most perfect instance of presence. By the definition we have presented of the word knowledge we may define epistemology as 'the science which discusses human knowledge and the evaluation of its types and the criteria of their validity.' ${ }^{44}$

Dengan demikian ilmu pengetahuan dapat dijadikan sebagai muqaddimah atau langkah awal bagi perbuatan yang baik, sebab ia dapat memainkan peran penting dalam konteks keberadaannya sebagai pendahuluan bagi keimanan dan fondasi bagi amal perbuatan (gerak ikhtiyârî) dalam proses menuju kesempurnaan.

Sayr was-sulûk qalbî dimulai apabila manusia mengetahui dan memahami tujuan tersebut. Kemudian ia pun akan melangkah pada jalan tersebut sesuai dengan kehendak serta pilihannya. Sebagaimana filsuf paripatetik yang berpandangan bahwa ilmu dan filsafat bukan sekedar mempunyai pengaruh bagi terwujudnya kesempurnaan. Akan tetapi keduannya merupakan hal yang bersifat prinsipil perihal tujuan dari kesempurnaan-kesempurnaan manusia. Menurut pandangan mereka bahwa manusia sempurna adalah manusia yang mempunyai pengetahuan burhân $\hat{\imath}$ yakni pengetahuan yang di dasarkan pada silogisme-demonstratif atas seluruh alam empirik.

Untuk dapat terwujudnya suatu keadaan mengetahui realitas, Misbâh Yazdî meniscayakan dengan melalui ilmu pengetahuan, namun melaluinya diharuskan mengandaikan adanya sejumlah elemen, mencangkup; subjek yang mengetahui, objek yang diketahui, serta atribut atau sifat yang

\footnotetext{
${ }^{43}$ Misbâh Yazdî, Philosophical Instructions..., hlm. 113.

${ }^{44}$ Misbâh Yazdî, Philosophical Instructions..., hlm. 113.
} 
disandang oleh sang subjek yang disebut 'ilmu' ('ilm). ${ }^{45}$ Akan tetapi pengertian analitis terhadap ilmu akan muncul ketika ia berupa ilmu atau pengetahuan berupa nafs (diri, aku) secara (hudhûrî) atas kewujudannya sendiri. Jadi ketika menjadi subjek yang mengetahui, diri adalah 'aqil, ketika menjadi objek yang diketahui, diri adalah ma'qul, dan ketika menkadi proses pengetahuan, diri adalah 'aql.

Pengenalan manusia terhadap alam semesta merupakan permulaan, yang bermula dari indra lahirnya dan interaksi anggota badannya dengan segala sesuatu yang berada di hadapannya. Aristoteles pernah bertutur "Barang siapa yang kehilangan satu indera, maka ia telah kehilangan satu ilmu," barang siapa yang kehilangan salah satu daya indranya, maka salah satu bentuk pengenalannya telah hilang.

Dan setiap dari perangkat inderawi ini melakukan kerjanya melalui operasi dan sistem tertentu dengan segala sesuatu yang merupakan objek "di luar" dengan cara mengirim sebagian kesadaran atau indikasi (atsar) berupa cahaya, suhu, aroma, dan rasa kepada syaraf dan kemudian menuju otak. Dengan cara seperti ini subjek yang bersangkutan dapat mempersepsi beragam kualitas dan kondisi yang berkaitan dengan beragam fenomena yang merupakan objek-objek materi yang berada dalam situasi tertentu yang berada di depannya. ${ }^{46}$ Dalam terminologi filsafat dikenal dengan aliran empirisme. Seperti ungkapan Epicurus, "semua yang mewujud dalam akal telah mewujud dalam pengindraan."

James Joyce di bukunya Man and His Nature, menyebut panca indra sebagai indra khusus, dikarena masing masing indra memiliki kualitas khusus, yang menyampaikan data secara khusus pula kepada kesadaran. Royce menafsirkan indra khusus seagai daya yang bisa mengantar manusia mengalami kualitas khusus yang ada pada objek material melalui rangsangan yang diterima oleh organ pencerapan. Selain indra khusus tadi, terdapat pula apa yang disebut dengan indra dalam (internal senses). Indra dalam adalah

\footnotetext{
${ }^{45}$ Istilah ilmu-berlaku pada kumpulan proposisi yang diduga saling bertautan. Lebih jauh, jelas sudah bahwa hubungan-hubungan yang berbeda memisahkan satu ilmu dengan dari lainnya. Dan bahwa hubungan terdekat antara berbagai masalah sebagai standar pemilihan ilmu adalah relevansi subjek-subjek mereka. Dengan kata lain, pelbagai masalah yang bersubjek terdiri atas bagian-bagian keseluruhan atau particular-partikulas universal bisa membentuk suatu ilmu. Oleh sebab itu, menurut Misbâh Yazdî, masalah-masalah ilmu terdiri atas proposisi-proposisi yang subjek-subjeknya berada di bawah payung topik induk (sebagai keseluruhan atau universal). Dan subjek ilmu adalah topic induk yang mencangkup pelbagai masalah. Lihat, Misbâh Yazdî, Philosophical Instructions..., hlm. 62

${ }^{46}$ Misbâh Yazdî, Jagad Diri, hlm. 36
} 
daya pengenalan atas objek kongkrit secara material via kualitas-kualitas yang diindrai dan dialami via indra khusus.

Namun menurut Misbâh Yazdî persepsi inderawi yang belum cukup untuk mengungkap, menyingkap dan mengenali hakikat, karena ia memiliki kekurangan.

Pertama, ia berelasi dengan kualitas-kualitas tertentu dari penampakan objek-objek yang terindera, rangkaian aksiden ( $\left.a^{\prime} r a ̂ d\right)$ serta tidak mencakup seluruh kualitas (kaifiyah)-nya, terlebih yang merupakan zat dan substansi sesuatu itu sendiri ataupun aspek-aspek yang tak terindrai darinya. Kedua, bidang persepsi inderawi ini terbatas hanya pada kondisi tertentu. Sebagai contoh, mata manusia tidak dapat melihat cahaya kecuali pada kisaran gelombang antara 0,04 mikron hingga 0,08 mikron. Karena itu tidak bisa melihat sinar ultra violet dan infra merah. Ketiga, persepsi-persepsi tersebut sangat terbatas dari segi keberlangsungannya. Mata hanya dapat menangkap kesan dari cahaya ${ }^{47}$ Seperti tidak semua gelombang suara dapat didengar oleh telinga, dikarenakan telinga hanya bisa memdengar gelombang suara yang memiliki frekuensi tertentu saja, lebih dari frekuensi tertentu telinga tidak akan mampu

Indra terbukti keliru dalam menangkap kesan-kesan objek eksternal, dan membuktikan bahwa persepsi inderawi belum cukup untuk memberikan informasi tentang alam eksternal dalam bentuk yang paling jelas. Oleh karena itu, demi mengetahui sesuatu sebagaimana adanya, manusia membutuhkan alat lain. al-Ghazali dalam kitabnya Misykat Al-anwar, melihat rasio sebagai cahaya dibanding indra. Alasannya karena akal mampu memahami kuiditas atau esensi dari suatu entitas, dan kemampuan ini tidak dimiliki oleh indra.

Namun pada akhirnya akal juga masih punya kelemahan. Yakni sebagaimana yang digaris bawahi oleh Mulyadi Kartanegara yakni, pertama, rasio atau akal memiliki sifat meruang, sehingga ia cenderung menggeneralisir sesuatu, dengan demikian tak mampu menangkap kekhasan sebuah entitas. Kedua, bagi Rumi dan Bergson, akal tidak mampu mengakses objek secara langsung, tapi aksesnya hanya mungin terjadi melalui mediasi. ${ }^{48}$

Maka dari itu kebenaran sendiri bermakna sesuainya objek yang dicerap dengan forma mental. Disamping itu, terdapat beberapa pengertian lain tentang kebenaran, yakni pengertian kebenaran bagi kaum pragmatis, "kebenaran adalah pemikiran yang berguna bagi kehidupan praktis

\footnotetext{
${ }^{47}$ Misbâh Yazdî, Jagad Diri, hlm. 36.

${ }^{48}$ Mulyadhi Kartanegara, Pengantar Epistemologi Islam, hlm. 27.
} 
manusia," atau dari golongan relativis, "kebenaran adalah pengetahuan yang cocok dengan dengan perangkat persepsi yang sehat,". Definisi ketiga berpendapat bahwa "kebenaran adalah apa yang disepakati oleh semua orang,"; definisi keempat menyatakan "kebenaran adalah pengetahuan yang bisa dialami secara indrawi." Menurut Misbâh Yazdî pengertian-pengertian di atas itu tidak tepat, karena menjauhi dari masalah asas nilai pengetahuan itu sendiri. ${ }^{49}$

The rationalists hold that the standard for recognizing the truth is 'the nature of the intellect' (fitrat-e 'aql). The propositions which are inferred correctly from self-evident propositions and which are really components of them are considered to be truth, while sensory and experiential propositions are considered valid to the extent that they are proved by the aid of intellectual arguments. On the other hand, empiricists hold that the standard for the truth of knowledge is capability of being proved by means of experience, and some of them have added that it must be proved by practical experience. $^{50}$

Kritik Misbâh Yazdî terhadap rasionalis yakni tidak adanya penjelasan tentang kesesuaian proposisi-proposisi swabukti dan fitrah (innate) dengan realitas. Setelah dengan cermat membayangkan subjek dan predikat proposisi-proposisi swabukti, kontan dan tanpa bantuan pengalaman, akal manusia bisa memastikan kesatuan keduannya. Mereka yang meragukan proposisi-proposisi semacam ini pasti diakibatkan oleh kekeliruan membayangkan subjek dan predikat ataupun karena terjangkit sejenis psikosis kejiwaan. Sedangkan kritik yang dialamatkan pada kaum empiris, bagaimanapun, jelas sekali bahwa tolak ukur tersebut hanya berlaku pada ranah yang bisa dicerap secara kasat mata, dan yang berkaitan dengan perkara yang dialami secara praktis. Tolak ukur ini pun tak bisa diterapkan pada logika dan matematika murni .

Namun demikian manusia masih mempunyai jalan pengenalan lain. Misalnya daya selain indra yang setelah terputusnya relasi anggota badan dengan alam materi masih dapat menjaga kesan yang diterimanya dari objek materi yang bersangkutan dengan cara khusus dan merefleksikannya pada kondisi-kondisi yang diperlukan pada lembaran-lembaran mental (dzihn) subjek yang mempersepsikannya, sebagaimana dzihn manusia juga mempunyai kemampuan lain untuk mengonsepsi serangkaian konsep universal (mafâhîm kulliyyah) dan selanjutnya mengkondisikan dzihn untuk

\footnotetext{
${ }^{49}$ Misbâh Yazdî, Philosophical Instructions..., hlm. 175.

${ }^{50}$ Misbâh Yazdî, Philosophical Instructions..., hlm. 176-177.
} 
melahirkan proposisi-proposisi asentual dan mempermudah kerja berpikir serta melahirkan kesimpulan-kesimpulan rasional yang meliputi bidang empiris maupun non empiris.

Dengan sarana daya internalnya, maka manusia mampu memperluas wilayah pengetahuannya dan menghasilkan sejumlah kesimpulan dari eksperimen-eksperimen serta kerja konseptualisasi inhern aksiomatik. Sesungguhnya kemajuan manusia menurut Misbâh Yazdî sangat bergantung pada daya-daya batiniah aqliyyah. Namun dengan tetap memperhatikan sisi perbedaan filsafat dengan sains. Sains lebih banyak menitikberatkan bidang kajiannya pada karakteristik dan pengaruh-pengaruh pada maujud (fisikal) untuk diambil kemanfaatan darinya guna terciptanya kehidupan yang lebih baik dan memudahkan segala aktivitas. Selanjutnya Misbâh Yazdî mengatakan bahwa tujuan mendasar dari filsafat adalah memahami quiditas dan esensi segala sesuatu dalam batasan yang memungkinkan dan hubungan kausalitas yang mengikat antara objek-objek tersebut. ${ }^{51}$

Jelas bahwa pemahaman yang sempurna atas eksisten (maujûd) tertentu tidak akan berhasil tanpa mengenali kausa-kausa eksistensialnya (al'ilal al-wujûdiyah), atau sebagai mana yang diungkapkan Ibnu Sina di dalam kitabnya Burhân asy-syifâ, yang sekaligus beliau komentari secara memadai. Ia menjelaskan dalam pernyataannya: "sesuatu yang bersebab (mempunyai kausa) tidak dapat dikenali melainkan melalui sebab-sebabnya" 52

Misbâh Yazdî membuktikan pengenalan akan realitas dengan meneguhkan prinsip hudûrî sebagai induk semua pengetahuan. Kemudian ia membagi dua macam objek pengetahuan: pertama, objek pengetahuan yang diperantarai oleh konsep "objek aksidental" yaitu objek yang tidak berkaitan langsung dengan subjek yang mengetahui ('alim) dan tidak menyatu dengannya; kedua, objek pengetahuan tidak diperantarai oleh konsep. ${ }^{53}$

Setelah menganggap 'ilm hudûrî sebagai induk semua pengetahuan, Misbâh Yazdî tidak larut dengan 'ilm hudûrî, namun memasuki ranah ilmu hush ûlî, ia menjelaskan pandangannya tentang prinsip badâhah. Ini sangat ditekankan demi memberikan jaminan nilai pengetahuan. Berikut penjelasannya:

Problem mengenai pengetahuan berkaitan dengan korespondensi antara pengetahuan dengan realitas. Problemini muncul akibat adanya garis

\footnotetext{
${ }^{51}$ Misbâh Yazdî, Jagad Diri, hlm. 38.

${ }^{52}$ Misbâh Yazdî, Jagad Diri, hlm. 38.

${ }^{53}$ Misbâh Yazdî, Philosophical Instructions..., hlm. 123.
} 
potongan antara subjek dengan objek. Tetapi, ketika garis potongan ini tiada, maka distingsi/masalah tadi menjadi tidak relevan. Dengan demikian, problem mengenai korespondensi pengetahuan dengan realitas disebut dengan pengetahuan husulli. Apabila pengetahuan dilekati nilai benar, maka kemustahilan pengetahuan itu menjadi keliru.$^{54}$

Mungkin akan timbul masalah: jika ilmu hudhuri itu adalah objek yang diketahui itu sendiri, itu berarti bahwa bentuk-bentuk mental merupakan ilmu hudhuri sekaligus ilmu hushuli. Hal itu karena, pada satu sisi, bentukbentuk mental diketahui dengan kehadiran, sedangkan bentuk-bentuk mental itu, pada sisi lain, merupakan contoh-contoh ilmu hushuli dari bendabenda eksternal. Jadi, bagaimana mungkin satu pengetahuan merupakan ilmu hudhuri sekaligus ilmu hushuli?

Misbâh Yazdî menyajikan argumen demikian: terdapat relasi representatif antara bentuk mental dengan realitas. Ilmu hushuli dengan demikian bermakna bahwa sebuah konsep berkaitan dengan benda eksternal. Sedangkan bentuk-bentuk mental yang hadir secara langsung dalam diri seseorang disebut dengan ilmu hudhuri. Kedua ilmu ini tentu berbeda satu sama lain; ilmu hudhuri berkaitan dengan presensi langsung pengetahuan di dalam diri, sedangkan ilmu hushuli berkaitan dengan pengetahuan mediatif, yang di dalamnya ada relasi antara pengetahuan dengan realitas.

Bagi Misbâh Yazdî, diri manusia sendiri bisa membagi kedua hal itu secara terpisah. Bentuk mental yang hadir secara langsung disebut ilmu hudhuri, sedang mental yang hadir secara tak langsung, karena ia membutuhkan konsep untuk mengetahui hal eksternal disebut ilmu hushuli. Pemilahan ini tidak terjadi di dalam konteks kemewaktuan, akan tetapi terjadi di dalam sudut pandang. Dengan demikian, sebuah bentuk mental bukan berarti tidak dapat disebut kurang hadir, hanya karena ia berstatus ilmu hushuli..$^{55}$

Sedangkan pengenalan pada tujuan tersebut dalam konteks pengenalan rasa (wijdâni) dan penyaksian (syuhtûtî) menurut Misbâh Yazdî, tidak akan terealisasi sebelum seseorang sampai kepada pemahaman terhadap tujuan itu. Oleh karena itu, sesuatu yang tak mungkin dapat dihindari bahwa ma'rifat atau pengenalan atas tujuan tersebut mestilah dengan menggunakan konsep-konsep mental rasional. Ketika makrifat ini

\footnotetext{
${ }^{54}$ Muhsin Labib, Pemikiran Filsafat..., hlm. 171.

${ }^{55}$ Misbâh Yazdî, Philosophical Instructions..., hlm. 129.
} 
semakin besar dan semakin tersadarkan, maka semakin besar pula peluang seseorang untuk merealisasikan kesempurnaannya.

Ilmu merupakan atribut eksistensial yang didapat oleh manusia. Ilmu tersebut bercorak hushûlli-rasional, Dan dengan ilmu itu, maka lenyaplah suatu 'ketiadaan' dan 'kecacatan'. Berdasarkan asumsi ini, maka ilmu adalah sesuatu yang diinginkan manusia berdasarkan fitrahnya. Namun menurut Misbâh Yazdî tidak setiap atribut eksistensial secara mutlak pasti merupakan kesempurnaan bagi penyandangnya. Sifat-sifat wujûdiyah tersebut adakalanya menjadi suatu 'kesempurnaan fundamental dan berealitas (ashlî) sebagaimana adakalanya sifat-sifat wujûdiyah juga merupakan kesempurnaan 'pendahuluan' dan nisbi. Kesempurnaan-kesempurnaan nisbi (relative) dapat dikategorikan sebagai 'kesempurnaan' bagi suatu eksistensi secara riil apabila ilmu dapat menjadi media atau sarana bagi peraihan kesempurnaan yang fundamental dan prinsipil..$^{56}$

Misbâh Yazdî membagi pengetahuan hushûlli menjadi dua yakni teoritis (nazariyah) dan praktis (amaliyah). Pengetahuan-pengetahuan teoritis meskipun tidak berkaitan secara langsung dengan perjalanan penyempurnaan manusia. Akan tetapi sebagian darinya, seperti ilmu-ilmu Ilahiah, memiliki peran dalam membantu manusia untuk mengenali tujuannya.

Semua pengetahuan teoritis, meskipun ia bukan merupakan pendahuluan bagi pengenalan tujuan atau jalan kepada tujuan tersebut, akan tetapi ia dapat memberikan kontribusi yang cukup baik dalam merealisasikan pengetahuan-pengetahuan "niscaya". Dengan demikian, manusia tidak diperkenankan memilah-milah jenis pengetahuan. Sebagaimana ilmu juga dapat berperan memenuhi kebutuhan-kebutuhan hidup yang tentunya ia mempunyai suatu nilai sebagai pendahuluan bagi sebuah kesempurnaan. Terpenuhinya berbagai fasilitas hidup yang dihasilkan dari penyingkapan banyak rahasia-rahasia dan fenomena alam fisikal, dapat menjadi pendorong dan perangsang seseorang untuk bersyukur dan beribadah kepada Allah.

Dapat ditekankan bahwa peran pengetahuan-pengetahuan yang bercorak hushûlli dalam kemajuan hakiki manusia tidak lebih dari hanya sebatas menyiapkan 'lahan'dan memperluas berbagai kemampuan dan kapabilitas yang terdapat pada manusia secara fitri.ia tidak mempunyai pengaruh yang bersifat 'pasti' dan dharûrî (tak terbantahkan) dalam peraihan kebahagiaan insane. Berdasarkan hal ini maka dalam pemaknaannya sebagai

\footnotetext{
${ }^{56}$ Misbâh Yazdî, Philosophical Instructions..., hlm..124.
} 
proposisi mental tidak dapat dianggap sebagai kesempurnaan secara actual bagi manusia dari sisi keberadaannya sebagai insan. Hanya saja ia dapat menjadi sarana atau perantara kepada Allah. ${ }^{57}$

Dengan penjelasan di atas, maka Misbâh Yazdî ingin mengkritik pandangan pragmatism yang meyakini bahwa sains dan teknologi akan mempunyai nilai kemanfaatan bagi diraihnya kehidupan yang lebih baik, atau merupakan substansi kehidupan. Menurutnya, perolehan ilmu pengetahuan, pengalaman dalam berteknologi, kerja individu bahkan aktivitas social sekalipun, tak satupun darinya dapat dianggap memiliki nilai mutlak. Meminjam istilah Frithjof Scchuon sebagai pseudo-ilmu. ${ }^{58}$ Suatu proposisi dalam memahami diri atau mengenali diri, manusia harus mempunyai seperangkat alat seperti yang sudah dipaparkan penulis di atas.

\section{b. Kembali Kepada Diri}

Merenungi apa yang ada di dalam diri dengan berbagai unsur yang hadir di dalamnya merupakan bentuk upaya kembali pada diri, dan hal ini tentu juga bertujuan untuk mengenali tujuan paling dasar (al-hadaf al-ashli) dan kesempurnaannya. Hal ini pun berkaitan dengan upaya peningkatan kualitas diri, dengan cara melakukan kontemplasi atas dimensi bathiniah diri sendiri.

Suatu hakikat yang dinamakan sebagai kesempurnaan akhir yang oleh Misbâh Yazdî di istilahkan dengan "kedekatan Ilahiah" (al-qurb al-Illahî), adalah suatu tahapan eksistensi dimana rangkaian kemampuan dan kapabilitas esensial seseorang, melalui gerak atau tindakan ikhtiyari-nya, mencapai tingkap aktualitas (fi'liyah), baik gerak yang dihasilkannya adalah gerak yang cepat sebagaimana yang terjadi pada nabi. ${ }^{59}$ Semua nabi telah menyeru manusia untuk mendekatkan diri kepada Sang Pencipta mereka dan agar manusia senantiasa mendekatkan diri kepada sumber ilmu dan kekuasaan yang tak terbatas.

Para nabi as telah menegaskan tentang kemungkinan dan peluang bagi terjalinnya dengan alam rububiyyah dan kesanggupan manusia untuk menerima pengetahuan-pengetahuan ghaib dan laduni melalui pemberitaanpemberitaan mereka terkait dengan mughayyabât (perkara-perkara di luar zona materi dan indrawi) dan penyingkapan mereka atas misteri-misteri tersembunyi serta melalui penjelasan-penjelasan mereka tentang pelbagai

\footnotetext{
${ }^{57}$ Misbâh Yazdî, Philosophical Instructions..., hlm. 135.

${ }^{58}$ Frithjof Schuon, Transfigurasi Manusia, hlm. 5.

${ }^{59}$ Misbâh Yazdî, Jagad Diri, hlm, 108.
} 
ilmu dan hikmah-hikmah yang mereka peroleh tanpa dengan proses mengkaji dan belajar. Oleh karena itu, hikmah Ilahi menuntut adanya sebuah jalan sehingga manusia dapat mengenal tujuan dan cara mencapainya; dan jalan itu adalah wahyu dan kenabian.

Dengan begitu kesempurnaan hakiki manusia adalah sebuah perjalanan 'ilm yang dialami ruh di kedalaman relung dirinya menuju Allah untuk sampai kepada suatu maqam, yakni suatu tingkatan kesempurnaan hakiki manusia. Pada tingkatan ini, manusia akan mendapati dirinya sebagai keterikatan dan keterpautan itu sendiri. Ia tidak mendapati kemandirian apapun pada dirinya dan pada semua maujud apapun baik dalam tataran zat, sifat, maupun perbuatan. Dan tidak ada suatu halangan apapun yang dapat mencegahnya untuk dapat mencapai penyaksian atas kenyataan tersebut.

Sesungguhnya suatu usaha dapat diatributkan sebagai daya upaya untuk peraihan kedekatan Ilahiah. Dan berada dijalan penyempurnaan hakiki, atau berada dalam nuansa insani adalah jika upaya tersebut bercorak 'ubûdiyah (penghambaan) dan peribadatan hanya kepada al-Haqq al-Ma'bud. Karenanya tidak mungkin menganggap suatu perbuatan dan aktivitas tertentu sebagai sesuatu yang melahirkan kesempurnaan hakiki jika ia menapaki jalan beribadah kepada Allah Swt.

Secara maknawi pengertian ibadah mempunyai pengertian yang beragam dan luas. Sebagaimana diutarakan oleh Misbâh Yazdî. Diantaranya: ${ }^{60}$ Pertama, ibadah adalah perbuatan yang dilakukan seseorang dalam rangka penegasan rasa 'ubûdiyah ke-haribaan Sang Khalik dan ia tidak mempunyai hubungan apapun secara substansial (fidzâtih) dengan selain Allah, seperti Shalat, puasa, dan haji. Sebagaimana yang dituturkan Ayatullah al-Jawad Amuli, bahwa shalat dilihat dari sisi konseptual merupakan kesatuan yang sepadan dengan eksistensi. Prinsip formatif dan maujud faktuak pada wilayah konseptual shalat berupa kumpulan gerak, diam, ucap, dan tindakan organ-organ tubuh. Seperti al-Qur'an memliki aspek i-tibârî semisal kumpulan hurup dan harakat dan aspek batiniah hakiki, berupa umm al-Kitâb, yang luhur nan bijaksana. ${ }^{61}$

Kedua, ibadah adalah perbuatan yang dilakukan seseorang dengan maksud memperoleh kedekatan (dengan-Nya) meskipun konteks awalnya tidak masuk dalam kerangka penegasan rasa kehambaan dan ia mempunyai

\footnotetext{
${ }^{60}$ Misbâh Yazdî, Jagad Diri, hlm, 116.

${ }^{61}$ Jawad Anuli dalam pengantar, Imam Khomeini, Shalat Makrifat: Seputar Makna Batiniah Gerakan Dan Bacaan Shalat (Bandung: Pustaka Hidayah, cet.2, 2006), hlm. 15.
} 
hubungan dengan hamba-hamba Allah lainnya, seperti khumus, zakat, jihad, dan amal ma'ruf nahi munkar.

Ketiga, ibadah adalah perbuatan yang dilakukan seseorang dalam rangka lil-qurbah (untuk memperoleh kedekatan kepada Allah) kendati keabsahannya tidak bergantung pada maksud dan tujuan ini. Ibadah meliputi semua amal dan perbuatan-perbuatan tersebut dilakukan dengan maksud lil-qurbah, maka ia adalah ibadah dalam pemaknaan ini.

Keempat, ibadah merupakan suatu bentuk kepatuhaan kepada maujud yang dipandangnya sebagai Yang Mandiri dan wajib ditaati, kendati ketaatan ini tidak bertolak dari maksud untuk menegaskan rasa kehambaan.

Tujuan fundamental manusia sesungguhnya adalah menggapai maqam kedekatan dengan Allah Swt. Perjalanan dan gerak perealisasiannya mengarah pada tujuan ini, yang merupakan tujuan perjalanan maknawi yang dimulai dari ruh di kedalaman kalbu manusia.

Langkah awal yang mesti ditempuh oleh seorang manusia dalam proses perjalanannya menuju puncak kesempurnannya yang berupa kedekatan dengan Allah adalah berupaya untuk memiliki keimanan. Langkah ini merupakan pondasi bagi langkah-langkah berikutnya dan sekaligus merupakan ruh bagi setiap tahapan peraihan kesempurnaan.

Bentuk penerimaan hati mengenai suatu hal yang sudah ditetapkan dan ditegaskan oleh akal pikiran, yang juga konsisten, serta tertuntut oleh sebuah tekad untuk melaksanakan konsekuensi-konsekuensi praktis (allawâzim al-amâliyah), merupakan pengertian dari sebuah iman. Dengandemikian, maka iman bergantung pada suatu pengetahuan atau pengenalan. Hanya iman tersebut bukan pengetahuan itu sendiri dan tidak pula ia secara pasti merupakan konsekuensi darinya (dari pengetahuan yang bersangkutan) $)^{62}$

Berdasarkan pemaparan diatas, bisa ditarik kesimpulan tentang bentuk hubungan yang terjalin antara pengetahhuan dan kepercayaan atau iman, bahwa amal pengetahuan mesti mengikuti iman. Akan tetapi ia bukan perbuatan eksternal (kerja fisik) itu sendiri. Tetapi lebih dari itu ia adalah rahasia, penggerak dan pembimbingnya. Sesungguhnya kesalehan, kepatutan serta kebaikan (dalam tataran pelaku) dari suatu perbuatan bergantung sepenuhnya pada iman.

Namun perlu digarisbawahi bahwa keimanan berbeda dengan pengetahuan mengenai Tuhan, tentang Wujud-Nya yang Esa, juga segala

\footnotetext{
${ }^{62}$ Misbâh Yazdî, Jagad Diri, hlm. 132.
} 
sifat-Nya, diantaranya antara lain seperti sifat al-kamâliyyah (kesempurnaan), al-jalâliyyah (keagungan), dll; juga pengetahuan mengenai kitab suci, hari akhir dan malaikat. Mukminnya seseorang tidak dipatok dari pengetahuan yang ia miliki tentang hal-hal yang tadi. Iblis adalah mahluk yang tidak beriman, namun ia memiliki segenap pengetahuan tersebut. Keimanan berkaitan dengan gerak hati; jika tidak masuk dalam hati, pengetahuan tidak bisa disebut sebagai keimanan. Setiap orang yang sudah mengetahui prinsip melalui metode rasional harus mengantarkan pengetahuannya itu ke dalam hatinya, dan menjadikannya sebagai tindakan hati berupa kepasrahan (taslìm) atau ketundukan atau penerimaan dan penyerahan diri (istislâm). Hanya dengan demikian maka seseorang menjadi mukmin. ${ }^{63}$

Pada akhirnya iman merupakan substansi dari keberadaan manusia, sebab Allah sudah menjustifikasi bahwa Ia akan memberikan kebahagian hakiki kepada manusia meskipun ia adalah sebuah amal shaleh yang mungkin mempunyai banyak manfaat di dunia untuknya dan orang lain. Allah berfirman:

Dan orang-orang yang kafir amal-amal mereka adalah laksana fatamorgana di tanah yang datar, yang disangka air oleh orang-orang yang dahaga, tetapi bila didatanginya air itu dia tidak mendapati sesuatu apapun. Dan didapatinya (ketetapan) Allah disisinya, lalu Allah memberikan kepadanya perhitungan amalamal dengan cukup. (Q.S. An-Nur: 39)

Orang-orang yang kafir kepada Tuhannya, amalan-amalan mereka adalah seperti abu yang ditiup angin dengan keras pada suatu hari yang berangin kencang. Mereka tidak dapat mengambil manfaat sedikitpun dari apa yang telah mereka usahakan (di dunia). (Q.S. Ibrahim: 18)

Sedangkan langkah selanjutnya dalam penyempurnaan insan adalah melakukan aktivitas melalui media hati setelah keimanannya kepada Allah Swt benar-benar mengakar tanpa harus memandang anggota badan. Atau dengan istilah lain, ber-tawajjuh (mengembara) menuju Allah Swt dengan dzikrullah (berzikir kepada Allah). Imam Ali Zainal Abidin dalam munajat alKẩifin (orang-orang yang takut kepada Allah) dengan penuh kerendahan berkata:

"Jangan engkau halangi para perindu-Mu untuk dapat menatap keindahan memandangi-Mu."

${ }^{63}$ Lihat, Khomeini. 40 Hadis: Telaah Atas Hadis-hadis Mistis dan Akhlak, hlm. 36. 
Di dalam munajat al-Muftaqirîn (orang-orang yang berkekurangan) beliau mengeluh kepada Allah Awt:

Kehausanku takkan terpuaskan kecuali dengan sampai kepada-Mu Kepedihanku tak'kan teredakan kecuali dengan perjumpaan dengan-Mu kerinduanku tak'kan terobati kecuali dengan memandang wajah-Mu ketentramanku tak'kan tenang kecuali dengan mendekat pada-Mu dukaku dapat dihilangkan hanya dengan kedekatan pada-Mu.

Dalam munajat Adz-Dzâkirîn (para penzikir) beliau mengungkapkan: Tuhanku! Kepada-Mu terpaut hati yang dipenuhi cinta Untuk mengenal-Mu dihimpunkan akal yang tercerai berai tiada'kan tenang kalbu kecuali dengan mengingat-Mu tiada'kan tentran jiwa kecuali ketika memandang-Mu aku memohon ampunan pada-Mu dari Setiap kelezatan tanpa mengingat-Mu dari Setiap ketenangan tanpa kesertaan-Mu dari Setiap kebahagiaan tanpa kedekatan dengan-Mu dari Setiap kesibukan tanpa ketaatan pada-Mu ${ }^{64}$

Dan langkah ketiga adalah melakukan aktivitas batiniah lainnya, berkonsentrasi pada Allah seperti bertafakur tentang ayat-ayat kauniyah Allah, tanda-tanda kekuasaan dan keagungannya beserta kemahabijaksananNya. Kontinuitas dan kelanggengan kondisi zikir dan tafakur mempunyai pengaruh yang tidak kecil dalam menimbulkan gelora, cinta dan keterpautan hati dengannya. ${ }^{65}$

Setelah melewati fase-fase ini semua barulah amalan-amalan jasmani dapat diterima artinya berperan sebagai perjalanan penyempurnaan. Dan jika objek seseorang adalah sesuatu yang berlawanan dengan tuntutan keimanan, maka hal tersebut akan melemahkan imannya. Jadi hubungan yang terjalin antara iman dan amal perbuatan adalah seperti hubungan antara akar tetumbuhan dan aktivitas menumbuhkan.

Sedangkan amal perbuatan yang buruk dan praktek maksiat, menurut pemikiran Misbâh Yazdî akan berdampak pada melemahnya iman dan pada gilirannya (jika berlangsung terus menerus) akan mematikan akarakar keimanan. Sebab akan membuat lupa manusia bahwa ia tercipta disertai dengan potensi, dan kapabilitas untuk menggapai kesempurnaan dengan melakukan gerak menyempurna (harakah istikmâliyah). Dan dari pembahasan ini dapat ditarik suatu simpul bahwa kesempurnaan akhir manusia yaitu

\footnotetext{
${ }^{64}$ Dikutip dari, Misbâh Yazdî, Jagad Diri, hlm. 90-93

${ }^{65}$ Misbâh Yazdî, Jagad Diri, hlm. 134.
} 
meraih hal tersebut dengan cara harus memobilisasi semua daya dan kekuatan yang dimilikinya untuk merealisasikan kesempurnaan hakiki, ketika tidak lagi merasa berjarak dengan Sang Illahi.

Bentuk penyatuan total dengan Allah atau Zat mutlak, hanya bisa dilakukan dengan cara Taqarrub atau mendekatkan diri kepada Allah, dengan cara melakukan nafilah, dengan orientasi mencapai kefanaan, yang mana hasilnya ialah "Aku menjadi telinganya yang dia pakai untuk mendengar dan seterusnya." Dengan demikian tersingkaplah bagi manusia sempurna yang berada di bawah nauangan Nama Yang Agung dan Besar, kemutlakan berbagai persaksian yang tetap dan azali-abadi. Tersingkap pula baginya ahwal segala penciptaan dan potensi-potensinya, berikut tata cara suluknya dan pertemuannya dengan hiasan cincin penutup dan penutup kenabian sebagai hasil dari suatu penyingkapan mutlak.

\section{Simpulan}

Manusia sempurna, menurut M. T. M. Yazdi antara lain meliputi:

1. Mahluk yang unik, ambigu, berkontradiksi pada dirinya sendiri, dan banal adalah hakikat dari manusia. Ia ingin menjadi sempurna, namun tidak tahu untuk apa menjadi sempurna. Ia ingin menjadi sempurna namun pada saat yang sama ia malah tergelincir pada lembah penyimpangan dari tujuan ihwal penciptaan. Melalui segenap pengetahuan mulai dari sains, teologi, antropologi, psikologi, berusaha mengurai manusia sebagai objek kajiannya, namun yang terjadi malah menjadi sub-sub pengetahuan yang berserakan, dari setiap subpengetahuan mengklaim nilai kebenaran yang absolut (grand-naration). Sehingga akhirnya manusia tidak pernah mengungkap ke-aku-an yang otentik, malah terjerumus pada kenihilan dan psimisme. Misbâh Yazdî melalui konsep filosofisnya ingin mengembalikan makna manusia pada Ada-nya, ia mengajak menelisik ulang eksistensi manusia pada melalui fakta kemenduniaan (being in the world) lalu bergerak menuju alam metafisis (ghaib). Yangh ia retas melalui fakta ilmu pengetahuan yang sudah ada, karena ia tidak menampik bahwa melaluinya (pengetahuan) jalan menuju kesempurnaan terbuka. Kemudian melampaui ilmupengetahuan.

2. Misbâh Yazdî adalah seorang penganut eksistensialis (ashâlat al-wujûd). Sehingga ia meletakan wujud (eksistensi) sebagai sumber dan prinsip kebaikan dan kesempurnaan, maka tak pelak wujudlah yang orisinil bukan esensi (mâhiyah). Sehingga konsep manusia sempurna Misbâh 
Yazdî mesti berangkat dari kesadaran akan keberadaan manusia untuk melakukan gerak menyempurna (harakah istikmaliyah) sebab pada dasarnya (fitriah) manusia bergerak menuju arah kesempurnaan, namun semuannya dikembalikan lagi pada pilihan dan kehendak bebas. Melalui jalan Ikhtiyârî dari tiap-tiap individu, karena pada hakikatnya sangat terkait dengan kemauan dan pilihan wujud yang sedang malakukan aktivitas 'gerak' itu sendiri kearah kesempurnaan.

3. Manusia merupakan mahkluk yang tak pernah tuntas, ia senantiasa berproses 'menjadi' (becoming). Berangkat dari asumsi itu maka sepatutnyalah kita mengabdikan hidup pada peraihan kesempurnaan. Menurut Misbâh Yazdî ada beberapa tahapan untuk sampai pada hakikat manusia seutuhnya maka yang pertama manusia harus mengenali dirinya sendiri. Pertama, Ma'rifat adz-dzat (mengenali diri), yakni menghayati keberadaannya sebagai makhluk yang mempunyai potensi dan kapabilitas untuk peraihan penyempurnaan insani. Kedua, Binâ' Adz-dzât (membangun diri), yaitu membentuk dan mengarahkan pada segenap rangkaian aktifitas keseharian manusia, melalui segenap pengetahuan baik itu pengetahuan umum atau keagamaan bukan memilah-milah apalagi membatasinya. Pada tahap inilah ditentukannya sebuah pilihan. Ketiga, Kembali Kepada Diri, setelah dua rangkaian diatas, seseorang mesti mengenali tujuan mendasarnya (al-hadaf al-ashli), dengan cara mengenali apa yang ada di dalam dirinya sendiri, yang membawanya pada perasaan dekat dan menyatu dengan Sang Illahi dalam arti kembali ke asal.[] 


\section{DAFTAR PUSTAKA}

Abidin, Zainal. Filsafat Manusia, Bandung: Remaja Rosdakarya, 2000.

Alwalid. Kholid, Perjalanan Jiwa Menuju Akhirat, Jakarta: Sadra Press, 2012.

Al-Ghazali, Abu Hamid. Hikmah Penciptaan Makhluk, Jakarta: Lentera, 2001, Cet.3.

Ali, Yunasril, Manusi Citra Illahi; Pengembangan Konsep Insan Kamil Ibn' Arabî Oleh Al-Jilli, Jakarta: Paramadina, 1997.

Arabî, Ibn'. Fusus al-Hikam, R.W.J Austin (ed), Jogjakarta: Islamika, 2004.

Armstrong, Karen. Sejarah Tuhan, Bandung: Mizan, cet.2, 2001.

Bagus, Lorens. Kamus Filsafat, Jakarta, Gramedia, 2000. . Metafisika, Jakarta: Gramedia, 2001.

Bahesti, Muhammad Husaini. Metafisika al-Qur'an, Bandung: Arasyi, 2003.

Bakker, Anton dan Zubair, Metode Penelitian Filsafat, Jogjakarta, Kanisius, cet. $15,2011$.

Bayrakti, Bayraktar. Eksistensi Manusia; Perspektif Tasawuf dan Filsafat Mengatasi Problema Eksisensi Manusia, Jakarta: Perenial Press, 1996.

Berlin, Isaiah. Four Essay On Liberty: Empat Esai Kebebasan, Jakarta: Pustaka LP3ES, 2004.

Fromm, Erich. Lari Dari Kebebasan, Yogyakarta: Pustaka Pelajar, 2007.

Hardiman, F. Budi. Heidegger dan Mistik Keseharian: Suatu Pengantar Menuju Sein und Zeit, Jakarta, KPG, cet. 2, 2008. . Filsafat Modern, Jakarta, Gramedia, cet. 2, 2007.

Heidegger, Martin, Being and Time, Terj. J. Macquarrie et al. New York: Harper and Row, 1962.

Izutsu, Toshihiko. Struktur Metafisika Sabzawari, Bandung: Pustaka, 2003.

Kartanegara, Mulyadhi. Menembus Batas Waktu: Panorama Filsafat Islam. Mizan: Bandung, cet.I., 2002. 2003. . Pengantar Epistemologi Islam, Bandung: Mizan,

Khomeini. 40 Hadis: Telaah Atas Hadis-hadis Mistis dan Akhlak, Bandung: Mizan, ed. Revisi. Cet. 2, 2009.

Labib, Muhsin. Pemikiran Filsafat Ayatullah Muhammad Taqi Misbah Yazdi, Jakarta: Sadra Press, 2011.

Moin, Baqer. Ayatullah Khomeini Mencari Kesempurnaan: Teori dan Realitas, dalam Ali Rahmena (ed.), Para Perintis Zaman Baru Islam, (Bandung: Mizan, cet. 3, 1998.

Muthahhari, Murtadha. Tema-Tema Pokok Nahj al-Balâghah, Jakarta: Lentera, 2001. 
. Mengenal Epistemologi, Jakarta: Lentera, 2001.

. Manusia Seutuhnya; Studi Kritis Berbagai Pandangan

Filosofis, Jakarta: Shadra Press, 2012.

Nasr, Seyyed Hossein Ed, Ensiklopedi Tematis Spiritualitas Isman, dalam, Charles Le Gai Eaton, Manusia, Bandung: Mizan, 2002.

Jogjakarta: Ircisod, 2006.

Nietzsche, Fridrich, Zarathustra, Jogjakarta: Bentang, Cet. 2, 2001.

Noer, Kautsar Azhari. Ibn' Arabî: wadat al-wujûd dalam perdebatan, Jakarta: Paramadina, 1995.

Serambi, 2002.

. Tasawuf Perenial: Kearifan Kritis Kaum Sufi, Jakarta:

Nur, Syaifan. Filsafat Wujud Mullâ Shadrâ, Jogjakarta: Pustaka Pelajar, 2002.

Radhi, Sayid Syarif, Nahj al-Balaghah; Sermons, Letters and Sayings of Ameer al-

Mu'minieen, the Commander of the Faithful, Imam Ali ibn Abi Thalib (a.s). Jakarta: Al-Huda, 2009.

Rahardjo, Dawam. Ensiklopedi al-Qur'an, Jakarta: Paramadina, 1996.

. Insan Kamil: Konsepsi Insan Menurut Islam, Jakarta: Pustaka Grafity Pers, 1987.

Shadra, Mulla. Manifestasi-Manifestasi Illahi, Bandung: Pustaka Hidayah, 2006.

. Kearifan Puncak, Jogjakarta: Pustaka Pelajar, cet. 2, 2004.

. al-Hikmah al-Muta'aliyyah fi Asfar al-Aqliyyah al-Arba'ah, Beirut:

Dâr Ihyâ' al-Turâs al-'Arabî, 1981, jil. I

Shihab, Quraish Wawasan al-Qur'an, Bandung: Mizan, cet.2, 1996.

Solomon, Robert C. \& Kathleen M. Higgins, Sejarah Filsafat,Jogjakarta, Bentang, 2001.

Sudarminta, Epistemologi Dasar: Pengantar Filsafat Pengetahuan, Jogjakarta, Kanisius, 2002.

Sugiharto, Bambang, Posmodernisme; Tantangan Bagi Filsafat, Jogjakarta, Kanisius, 1996.

Syari'ati, Ali Tugas Cendekiawan Muslim, PT Raja Grafindo Persada: Jakarta, 1996

Syarif, M.M. Para Filosof Islam, Bandung; Mizan.

Thabâthabâ'̂̂, Muhammad. Islam, Dunia dan Manusia, Lembaga Internasional Ahlul Bait: Iran.

Takesita, Masataka, Insan Kamil Pandangan Ibn' Arabî, Surabaya, Risalah Gusti, 2005. 
Yazdî, Muhammad Taqî Misbâh. Philosophical Intruction: an Introduction to Contemplary Islamic Philosophy (Istitute of Global Cultural Studies: University of Binghamton, 1999) . Jagad Diri, Jakarta: Al-Huda, 2006. . Freedom, Jakarta: Al-Huda, 2006.

Jakarta, al-Huda, 2005. . Iman Semesta, terj. Ahmad Marjuki Amin, Jakarta: Lembaga Internasional Ahlul Bait.

Meniru Tuhan: antara 'yang terjadi' dan 'mesti terjadi', Jakarta, Al-Huda, 2006.

Yazdi, Mehdi Hairi Menghadirkan Cahaya Tuhan, Bandung: Mizan, 2003 